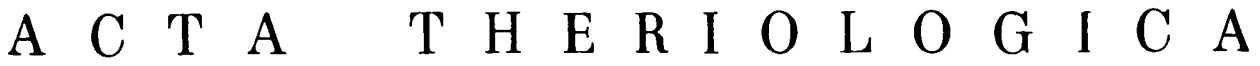

VOL. XI, 4: 71-127.

BIAŁOWIEŻA

$30 . X .1966$

\author{
Alina K O W A L K A - D Y R C Z
}

\section{A Comparative Study of the Male Genital Tract in Some Species of Shrews}

\author{
[With 2 Tables \& 55 Figs.]
}

The present paper has been concerned to the analysis of anatomical and histological structures of vas deferens, pars pelvina urethrae and accessory glands in the males of Sorex arancus Linnae us, 1758, Sorex minutus $\mathrm{L}$ i in na e us, 1766 and Neomys fodiens, (P e n n a t, 1771). The site of $\mathrm{gl}$. accessoriae buds and the manner of their formation in the course of embryonic development have been established. The obtained data have allowed to state the homology of the following $g l$. accessoriae in all investigated species: (1) One pair of gl. ampullarum, lying - within muscular walls of the distal portion of vas deferens. (2) One pair of gl. prostaticae which empty into the urethra by means of one pair of ducts ( $N$. fodiens and $S$. araneus) and by two or more pairs of ducts (S. minutus). (3) One pair of gl. bulbo-urethrales with a pair of long excretory ducts emptying into the sinus urethrae bulbi. In all investigated species the absence of gl. urethrales has been stated.

In all species in question the structure of pars pelvina urethrae is similar. Pars prostatica is lacking a blind diverticulum, described by Godet (1951) in Crocidura russula (H e rman n, 1780) as a prostatic diverticulum. There is instead a pocket-like, well developed (in gen. Sorex in particular) sinus urethrae bulbi occurring on the boundary between pars membranacea and pars spongiosa urethrae.

I. Introduction

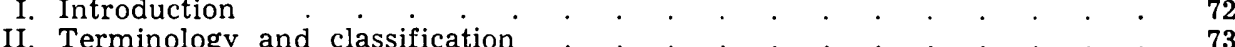

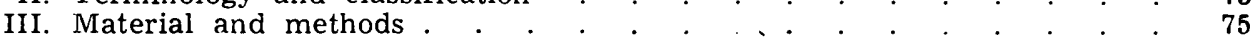

IV. Structure and development of the genital tract and its glandulae accessoriae

A. Sorex araneus Lin na e s, 1758 .

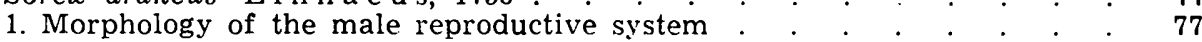

2. Vas deferens (Wolffian duct) . . . . . . . . . . . . . . . 78

3. Glandulae prostaticae . . . . . . . . . . . . . . . . . . . . . 81

4. Urethra . . . . . . . . . . . . . . . . . . 83

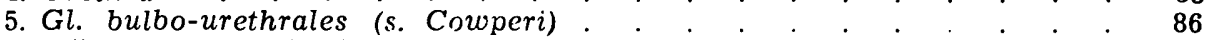

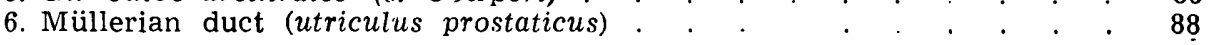


B. Sorex minutus L in na u s, 1776 . - . . . . . . . . . . $\quad . \quad 88$

1. Morphology of the male reproductive system . . . . . . . . . . . . $\quad 88$

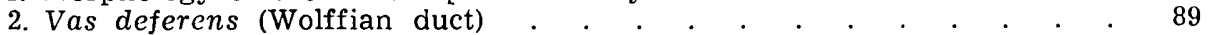

3. Glandulae prostaticae . . . . . . . . . . . . . . . . . . 50

4. Urethra . . . . . . . . . . . . . . . . . . . 91

5. Gl. bulbo-urethrales (s. Cowperi) . . . . . . . . . . . . . 94

6. Müllerian duct (utriculus prostaticus) . . . . . . . . . . . . . . 94

C. Neomys fodiens (P e n n a n t, 1771) .

1. Morphology of the male reproductive system . . . . . . . . . . $\quad . \quad 95$

2. Vas deferens (Wolffian duct) . . . . . . . . . . . . . . . . $\quad . \quad 96$

3. Glandulae prostaticae . . . . . . . . . . . . . . . . . . . . 57

4. Urethra

5. Gl. bulbo-urethrales (s. Cowperi) . . . . . . . . . . . . 101

6. Müllerian duct (utriculıs prostaticus) . . . . . . . . . . . . 102

V. Discussion

1. Vas deferens (Wolffian duct)

2. Gl. prostaticae

3. Urethra

4. Gl. bulbo-urethrales

5. Müllerian duct (utricuius prostaticus) $\cdot \cdot \cdot \cdot \cdot \cdot \cdot \cdot \cdot \cdot \cdot \cdot 112$

6. General remarks.

References

Streszczenie

Explanation of plates

\section{INTRODUCTION}

The investigations of the male genital tract in Insectivora were started in the last century (O u demans, 1892). The research of such authors as D is selhorst (1904), Rauther (1904, 1938), Grosz (1905), Är n bäck-Christie- Linde $(1907)$ and $\mathrm{K}$ a u der $\mathrm{n}(1907$; 1911) have contributed to the better knowledge of this problem. The first four above mentioned authors have described the male reproductive organs in the mole and the hedgehog, $\ddot{A r n b a ̈ c k-C h r i s t i e-~}$ $-\mathrm{L}$ in $\mathrm{de}$ (l.c.) who had studied their anatomy in Soricidae gave some descriptions of the microscopic structure of those organs, whereas a general review of the anatomy of the male genital organs in the representatives of almost all families of the Insectivora, Soricidae including, is due to $\mathrm{K}$ a u de $\mathrm{rn}$ (1911). So far, his paper has been the only comparative study of such a large scope; nevertheless it does not deal with microscopic structure or the development of the organs in question.

All the quoted investigations have undoubtly contributed to the knowledge of the structure of the male reproductive system in Insectivora but none of them has explained the homology of the accessory glands. The accessory glands in the hedgehog well illustrate this problem being described by various authors in different terms. Similarly, paired glands lying dorsally to the urinary biadder in shrews have been defined by Brambell (1935) as vesiculae seminales, while, according to the later investigations on their development ( $\mathrm{Eadie}, 1947$ ) they appeared to be the prostatic glands.

Although a first correct classification of the accessory reproductive glands in Mammals, based on developmental data (see Terminology) is due to $\mathrm{R}$ a $\mathrm{u}$ ther (1904), nevertheless, the analogical investigations in Insectivora have been started as late as in nineteen forties. The results of such authors as M o m ba e r t s (1944), Eadie $(1947 \mathrm{a} ; 1947 \mathrm{~b} ; 1948 ; 1951)$, Godet $(1949 ; 1950 ; 1951 ; 1952)$ and $\mathrm{Peyre}$ (1959) who had studied (sometimes also experimentally) the development of the accessory glands and the associated genital tracts in Talpidae, Erinaceidae and Soricidae, have been a starting point for a correct classification of those structures 
based upon the principle of homology. So far, however, only the first two families have been correctly classified. As to the Soricidae we are still deficient in the data concerning the microscopic structure of the accessory glands in fully grown individuals. This, in spite of some developmental data ( $\mathrm{E}$ a di e, $1947 \mathrm{~b}$ ) established the origin of accessory glands buds in Sorex cinereus (K e r r, 1792) and in Blarina brevicauda (S a y, 1823), and Godet gave a brief information concerning their formation in Crocidura russula (H e rma $\mathrm{n}, 1780$ ) makes difficult their correct classification. The following criteria are essential to determine the homology of the accessory glands within any order of the mammals: 1) the manner and site of the formation of their buds in the genital tract; 2) their microscopic structure; 3) the localization of the openings of their excretory ducts with respect to other structures. Since these criteria have been formulated quite recently, the monographs of many species ought to be reviewed and some new investigations should be conducted in an adequate manner. It is the only way to avoid the ambiguity in terminology, which in turn, makes difficult any correct classification.

In the present study on the male reproductive tract in Sorex araneus $\mathrm{L}$ in $\mathrm{n}$ a e u s, 1758, Sorex minutus Linnaeus, 1766 and Neomys fodiens (P e n n a t, 1771) I have tried to take under consideration all criteria given above. The investigations have involved only the true accessory reproductive glands as well as the portions of genital tracts associated with them, the perineal and rectal glands being only loosely connected with the process of reproduction have been neglected. The exterior genital glands - the glandulae praeputiales which in small mammals are of a great taxonomic value ( $\mathrm{Kr}$ a to chvil, 1960) are not present in shrews. This phenomenon has been stated by the authoress in the course of her investigations and confirmed by the data found in the literature.

\section{Acknowledgement:}

The authoress expresses her gratitude to Professor Janina Orska, the head of the Department of Comparative Anatomy, for the most valuable remarks given her in the course of writing this paper, as well as in reading the typescript, and to Dr. Z. Pucek of the Mammals Research Institute in Białowieża who made available to her the preserved material from the collection of the Institute. The authoress thanks also B. Kokurewicz, M. Sc. for his help in preparing the plates.

\section{TERMINYLOGY AND CLASSIFICATION}

Although the first comparative studies were started as early as in the last century ( $\mathrm{L}$ e y dig, 1850, O u d e man s, 1892) the problem of a correct terminology and classification is still discussed. R a u the r (1904) is the first author who has based his system of classification on the developmertal data. He distinguished ihree groups of glands according to their origin: 1) the glands developed from the vas deferens, 2) the glands derived from canalis urogenitalis, 3) the glands formed from the epidermis of the inguinal, rectal and preputial regions. M o s s m a n (1932) put a stress on the epithelial origin of the buds of glands (it was possible owing to studies on the origin of the epithelium of the very urogenital canal). This author has distinguished the following groups of glands: 1) the glands developed from the distal portion of vas deferens, 2) the glands developed from the entodermal portion of the sinus urogenitalis, 3) the glands formed by the proximal end of the Mullerian duct, 4) the glands formed from the ectoderm of preputial and inguinal regions. II os sman (l.c.) in his terminology has attempted to apply the terms used in the anatomy of man. 
The classification given by $\mathrm{G}$ od e $\mathrm{t}$ (1952) is the most modern system based upon both developmental and experimental data. This system being a further modification of $\mathrm{R}$ a u th e r's classification (1904) does not differ essentially in its terminology. The following groups have been distinguished:

A. The glands controlled by the male hormones

I. The glands developed from the Wolffian duct: they may take different position but have the same origin. Considering their position one distinguishes:

1. the glandulae ampullarum $\left(\mathrm{A}_{1}, \mathrm{~A}_{2}, \mathrm{~A}_{3}\right)$ : they are placed within the muscular walls of the vas deferens. Their respective positions being the terminal, central and initial portions of the deferent duct.

2. the vesiculae seminales: a paired structure described as the outpouching of the ductus deferens. They either join the deferent duct or empty independently into the urethra.

II. The glands developed from the entodermal portion of the sinus urogenitalis, placed in the neighbourhood of the crista urethralis and colliculus seminalis. They originate from the ventral or lateral walls of the urethra ${ }^{1}$ ): glandulae prostaticae.

III. The glands developed from the ectodermal portion of the sinus urogenitalis ${ }^{2}$ ): the glandulae bulbo-urethrales ( $s$. Cowperi) (most of ten they occur as one-paired structure). The glands open anteriorily to the bulbus and have a long excretory duct.

B. The glands weakly influenced by the sex hormones.

1. The glandulae para-urethrales (Littré): they do not leave the mucous membrane being dispersed alongside of the urethra.

2. The glandulae praeputiales.

3. The glandulae inguinales and perineales.

C. The glands formed by the remnants of the Müllerian duct: since they are exceptional structures their true nature should be defined for each species separately. They are called: the utriculus prostaticus, the uterus masculinus and the vagina masculina.

1) G o det (1952) quotes the data obtained by Z u c kerman (1940) and B ur n S (1942) concerning the possibility of ectodermal origin of the dorsal wall of the pars prostatica urethrae in mammals. Following these results Godet (1952) considers to be homologous only those prostatic glands that develop from the ventral and lateral walls of the urethra. The so-called dorsal lobes of the prostate, which among others, occur in Rodentia, are probably of ectodermal origin, therefore their correct place in the system ought to be kept open for further explanations. Each species should be treated separately and carefully studied before the definite conclusions are drawn. This last statement of $\mathrm{G}$ o d e $\mathrm{t}(l . c$.) has been confirmed by B e n g m a rk (1958) who studied the development of pars prostatica urethrae in the rat and found that it originates from the entodermal epithelium of the cloaca. This finding has in turn confirmed the homology of all three groups of the prostatic glands that occur in the above species.

2) The investigations of Barstein \& Mossman (1938) carried out on $\mathrm{Ta}$ miasciurus hudsonicus ( $\mathrm{E} \times \mathrm{x} \mathrm{le}$ b e $\mathrm{n}, 1777$ ) and of $\mathrm{Siddiqui}$ (1937) on Citellus tridecemlineatus (=Spermophilus tridecemlineatus Mitchill, 1821), suggest the ectodermal origin of the spongy part of the urethra in mammals (quoted after G o d e t, 1952). 
In the present paper the terminology assumed for the accessory glands in shrews follows that proposed by G odet (1952).

The portion of the canal lying between the openings of urinary bladder and deferent duct is described in comparative anatomy as the urethra sensu stricto, or following the terminology assumed in anatomy of man: the pars prostatica urethrae, or simply, the prostatic urethra. This portion encloses the following regions: the crista urethralis and the colliculus seminalis. Farther portion of the canal enclosed by the openings of vasa deferentia and by the orificium externum urethrae on the glans penis is termed the true canalis urogenitaiis. The true canalis urogenitalis consists of the following portions: pars pelvina (from the openings of vasa deferentia. to the level of crura penis), and pars phallica. Most authors, however, assume for the true canalis urogenitalis the nomenclature taken from the anatomy of man and describe the pars pelvina canaiis urogenitalis as the pars muscularis or pars membranacea urethrae, and the pars phallica as the pars spongiosa urethrae or the pars cavernosa penis. A bulb, which in mammals occurs in a level with crura penis, is formed by the proximal part of corpus spongiosum penis and coated dorsally by the $m$. bulbo-cavernosus. In anatomy of mar this bulb is defined as the bulbus corporis cavernosi urethrae or the bulbus penis. In comparative anatomy, it is known as the bulbus urethrae. This last term, however, is ambiguous being used by $\mathrm{M}$ ombaerts (1944) to define the swelling of pars prostatica urethrae occurring in the mole and the hedgehog which has nothing in ccmmon with the true bulpus.

An urogenital sinus usually found in the bulb and associated with the openings

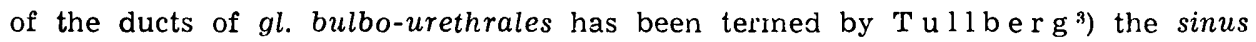
urethrae. This term is commonly applied in mammals (a modification of this term: the sinus urethralis can be also used). M os sman (1932) who wanted to put stress on the relation between the sinus and the bulbus penis has suggested the term sinus urethrae bulbi, which seems to be quite reasonable. A dilated portion of the lumen of the urethra which in man occurs in the same level, i. e. in a level with the openings of the ducts of gi. bulbo-urethrales has been called the ampulla urethrae. This term, however does not seem to be appropriate for this usually pocket-like sinus occurring in mammals.

In the present paper the terminology assumed for the urogenital canal follows that used in anatomy of man ( $\mathrm{t} t \mathrm{e} \mathrm{m}$ a s i a k, 1958). It has been, however, completed by the term suggested by M os $\mathrm{m}$ a $\mathrm{n}$ (1932) the sinus urethrae bulbi.

\section{MATERIAL AND METHODS}

The embryos and genital organs of young males (immature sexually) and adult individuals (mature sexually) of three species of shrews, namely: Common Shrew, Sorex araneus Linnae us, 1758, Lesser Shrew, Sorex minutus L in na e us, 1766 and European Water Shrew, Neomys fodiens (Penn a $t, 1771$ ) have come chiefly from the material collected by the Mammals Research Iristitute of the Polish Academy of Sciences at Białowieża, and from the material (this concerns Cornmon Shrew in particular) collected by the authoress in Strachocin forest near Wrockaw during the years $1958-61$.

3) Tullberg T. 1899: Ủber das System der Nagetiere. Nova Acta Regiae Soc. Upsalensis (cited after K. S z a r s k i, 1935). 
The numerical data concerning the material usea for the investigations have been presented in Table 1.

Since the embryonic material came from captures the only available criterion to establish the sequence of developmental stages was the length of the embryo. The measurements carried out by means of compasses were taken from the top of the read to the root of tail. This method, however, is not very accurate, because of the varying degree of the coiling of embryos. Since the reproduction of captured shrews has appeared to be nearly impossible ( $\mathrm{Dehnel}$, 1952) the investigated material being collected at random were missed some stages of embryonic development. (The females being in an advanced pregnancy were very rarely captured). Despite my efforts I have not succeeded to find any nest. Consequently neither the newborn nor the nestlings could be investigated. Nevertheless, the chief purpose of the present work has been reached. The carried out investigations have appeared to be successful in detection of the site and manner of buds formation of the accessory glands. These findings together with the analysis of the structure of those organs in fully grown animals have allowed to establish their homology.

Table 1.

Numbers of animals studied.

\begin{tabular}{|l|c|c|c|}
\hline \multicolumn{1}{|c|}{ Species } & Embryos & young males & sexually mature males \\
\hline S. araneus & 6 & 5 & 4 \\
S. minutus & 6 & 2 & 9 \\
N. fodiens & 5 & 3 & 3 \\
\hline
\end{tabular}

Since, as a rule, the males of shrews do not attain sexual maturity in the first calendar year of their life (P u c e, 1960$)$, and their life cycle involves only one reproductive season (from March to October) the structure of a population, as far as the age is concerned, is very simple. Hence, the division of the whole population into young and fully grown individuals has not been difficult, being based upon such characters as body weight, hairing, the state of dentiton, the dimensions of genital organs etc. The age of young males (termed here juvenile stage) ranged within 6 weeks to 2 months.

Fixation and staining methods. Both embrycs and genital organs of mature males have been fixed in Bouin's fluid, only a part 'of Common Shrew embryos being fixed in Zenker's fluid. A series of paraffin wax slices consisted of cross sections and a number of longitudinal sections. All slices were $\bar{j}-7 \mu$ thick. In embryos the whole posterior part of the body was sectioned, while in fully grown individuals only the urogenital complex or its fragments were sectioned.

The preparations have been stained by Heidenhain's hematoxylin and eosin, by Delafield's hematoxylin and eosin, and by Heidenhain's ("Azan") method.

In order to improve the studies of the canalis urogenitalis some preparations were made by taking advantage of a binocular. The whole complex of the canal had been cut into a series of slices later examined in a clearing fluid (benzene). This 
method has successfully completed the obtained results, since its has permitted to astablish an accurate plane of the section, this being not always possible in microtomic series.

\section{THE STRUCTURE AND DEVELOPMENT OF THE GENITAL TRACT AND ITS GLANDULAE ACCESSORIAE}

\section{A. SOREX ARANEUS L I N N A E US, 1758}

\section{The morphology of the male reproductive system}

The descriptions of the male genital system in Common Shrew have been given by $\ddot{A}$ rnbäck-Christie-Linde (1907), Ka udern (1911), B r a m bell (1935) and Wols ka (1952). Nevertheless, a brief description of this system seems to be necessary.

The testes are lying in cremaster sacs near the posterior end of the pubic bone (their position is invariable). The epididymis built in typical way, adheres the median surface of the testes. The deferent duct issued from the tail of the epididymis has two distinct swellings: the proximal swelling (the swelling " $a_{1}$ " after the terminology of A r n äck- Christie-Linde) whose diameter in the mature male is $1.3 \mathrm{~mm}$, and the distal one which continues to the entrance of the ductus deferens into the wall of the urethra (the swelling " $a_{1}$ " in the terminology assumed by $\ddot{A}$ r n b ä c k-Christi e - L i n d e), its diameter is circa $3.2 \mathrm{~mm}$. This last swelling is pear-like shaped (Fig. $1 \mathrm{a}$ ).

A pair of glands lying dorsally to the ductus deferens and to the urinary bladder has a clotty structure and an irregular shape. In the males sexually mature their average diniensions are $10 \mathrm{~mm} \times 6 \mathrm{~mm}$. These are the glandulae prostaticae (Fig. 1 p). The bladder passes dorsaly into the urethra which courses caudally, its pelvical portion being uniformly distended. A well-developed bulb - the bulbus penis occurs at the root of penis (Fig. 1, b). After having left the bulb the penis courses at first cranially, then it takes a caudal direction (for a short distance) to change it into a cranial one, finally, its distal portion is directed caudalwards. This double sigmoid bending observed in a resting penis and undoubtly associated with its exceptionally large dimensions, is characteristic for the shrews belonging to Sorex L.

Outside the pelvical cavity, at both sides of the root of the tail we see a pair of elongated, crescent-like and slightly flattened dorso-ventrally glands, whose cranial ends are deflected from the long axis of the body. These are the $g l$. bulbo-urethrales. Their average dimensions in the male mature sexually are $5 \mathrm{~mm} \times 2.3 \mathrm{~mm}$. (Fig. $1 \mathrm{c}$ ). 


\section{Vas deferens (Wolffian duct)}

A. Sexually mature male

Initial portion. Immediately after leaving the tail of the epididymis the diameter of the ductus deferens is circa $300 \mu$, its inner structure can be described in the following way: The epithelium lining the lumen is double-layered, thrown into longitudinal folds of moderate height. The inner layer is built of prismatic cells with round or oval nuclei, placed in the basement of the cell. The apical ends of the cells are provided with long stereocilia. The basal layer consists of low cells poor in cytoplasm with oval nuclei. The epithelial canal is surrounded by a thin layer of connective tissue and a thick layer of muscles, consisting of smooth muscle with circularly disposed fibers, only their outer most part is disposed longitudinally. In the lumen of the canal one often sees numerous spermatozoa mixed with flacky or droplat-like secretion staining feebly with eosin. The evidence for the secretory function of the epithelium lining this portion of the duct is given by stereocilia which are usually glued together, and whose distal encls bear sporadically the droplets of secretion (Fig. 2).

Proximal swelling of the ductus deferens. In its further course the diameter of the ductus deferens gradually increases initiating the so-called proximal swelling. The maximum diameter of the swelling is circa $1.3 \mathrm{~mm}$. This swelling (as shown by microscopic sections) has been caused not only by an increased diameter of this portion of the epithelial duct but also by an exceeding folding of its walls which eventually results in numerous sinuses, even in lateral pockets emptying into the main lumen. (On Fig. 6 we see a cross-section through this portion of the deferent duct in S. minutus, an identical picture is seen in S. araneus). The muscular wall of this swelling is continuous with the muscularis of the initial portion of the ductus deferens. A cross section through the ductus deferens shows two distinct layers of the muscular wall. The arrangement of muscular fibers both in circular and longitudinal layers is, however, not regular (Fig. 6). From the analysis of the ductus deferens sectioned transversally and longitudinally it follows that the muscular membrane consists in reality of spiral fibers. These spirals are more steep in the outer layer being rather horizontally disposed in the inner layer. Hence, the effect of a bilaminar structure. In the ductus deferens in man in addition to the two described above layers there is also "an inner layer of muscular fibers disposed longitudinally" (S tö h r, 1963). The epithelium lining the crypts and pockets differs somewhat from that lining the initial portion of the ductus deferens. It should be defined as pseudostratified rather than double-layered, since the basement cells, 
described above, do not form a continuous layer but are wedged here and there between the prismatic cells lining the lumen of the canal. These last cells are equipped with long stereocilia (Fig. 7). The epithelium lining this portion of the ductus deferens has also secretion ability, since the droplets of secretion detached from the apical pcle (sporadically club-shaped) of the cell and flowing down along the cilium into the lumen of the canal are frequently seen. The central lumen and the pocket are as a rule filled with spermatozoa mixed with a clotty secretion. Small grains which can be sometimes seen come probably from the decomposition of the spermatozoa's heads. At the beginning of the breeding scason (April) the proximal swelling in addition to the tail of epididymis performes the role of true seminal storehouse being filled with a compact mass of sperm (Fig. 9).

Distal swelling of the ductus deferens (gl. ampullarum). This swelling is separated from the proximal one by an isthmus found in the mid-portion of the deferent duct. The swelling forms a true ampulla of the ductus deferens. Because of a distinct glandular character of this structure (Fig. 10) the two distal swellings have been termed the $g l$. ampullarum following the terminology assumed for the accessory glands in Mammals.

The muscular wall of this swelling is continuous of the muscularis of the ductus deferens, although it consists chiefly of the muscular fibers arranged in horizontal spirals (giving the impression of a circular layer when seen on a cross-section through the ductus deferens). The central lumen of the glands is also continuous with the lumen of proximal portion of vas deferens. A system of tubes and pockets appears in walls between the muscular layer and the central canal. Both tubes and pockets empty into the central canal which is filled with secretion. The pockets are tightly arranged being separated one from another by a small amount of connective tissue. Their arrangement is slightly looser in portion surrounding the central canal, where the amount of connective tissue is somewhat greater (Fig. 10). The epithelium lining the tubes is either prismatic or isoprismatic depending on the functional state of the ceils. The round nuclei are lying in the basal portion of the cells. Binucleated cells are not very rare. Because of a sporadic occurrence of flattened basement cells wedged between basal portions of the secretory cells there must exist a relation between the described above epithelium and that of the ductus deferens. During an increased secretion the glandular cells are getting very tall and their distal poles are either clubby or bottle-neck shaped due to the accumulated secretion. This parts of cells are usually more basophilous than the remaining protoplasm. (Fig. 12). The secretion is either eccrine or apocrine, since either the 
whole plug is detached from the cell (apocrine secretion) or a nubble of course-grained secretion is detached from the apical pole of the cell, which does not change essentially its height (eccrine secretion). The secretion deposited in the lumen of the pocket is rather uniform; only here and there some fine-grained nubbles can be found. At the beginning of breeding season (April) the tubes become distended being filled with secretion which stains blue by Heidenhain's "Azan" method. The glandular epithelium is then very low, the nuclei are distinctly flattened. Similar pictures may be seen at the end of breeding season (from August to October). The lumen of the central canal as well as the lumina of some pockets are filled with a relatively great number of spermatozoa. The lumen of the central canal of the gland is lined with an epithelium showing the secretory activity and resembling that which lines the pockets. The stereocilia which are characteristic for the epithelium lining the proximal portion of the ductus deferens have been never seen. The glandular tubes which continue up to the crista urethralis do not disappear earlier than at the end of this portion of the urethra. Immediately before the opening on colliculus seminalis the epithelium of the ductus deferens takes the appearance of the stratified "urethral" epithelium of the urethra.

\section{B. Embryonic development}

The following three embryonic stages have been distinguished: Stage I - the embryos $8.5 \mathrm{~mm}, 8.6 \mathrm{~mm}$ long, stage II - the embryos $10.8 \mathrm{~mm}$ and $11.6 \mathrm{~mm}$ long, stage III - the embryos 14.2 and $14.5 \mathrm{~mm}$ long.

Stage I. The well developed Wolffian ducts empty into the urogenital sinus, caudally to the openings of the ureters. Both pairs of ducts are already well differcntiated. (The distance between their openings is equal to circa $40 \mu$ ). The Wolffian ducts within their entire length are built of a single-layered prismatic epithelium with large oval nuclei placed in basal portion of the cell. The cytoplasm is feebly stained with eosin. The lumina of the ducts are distinct, their diameter is 28 !", being slightly wider in terminal portion $(30-32 \mu$ in diameter). The Wolffian ducts which within plica genitales course medially to the Müllerian ducts, enter the funiculus genitalis exteriorily to them. (The mutual crossing of both pairs of ducts has taken place). Ever since the Wolffian ducts continue obliquely toward the urethra, exteriorily to the Müllerian ducts, and empty into the sinus urogenitalis on the dorso-lateral eminences of its dorsal wall, making almost the right angle (Fig. 53, W).

Stage II. Neither the course nor the development of Wolffian duets have been changed in this stage. 
Stage III. The distance between the opcnings of Wolffian ducts and such of the ureters amounts to $150 \mu$. The diameter of the ducts has remarkably increased (being in cranial and terminal portions $32 \mu$ and $36 \mu$, respectively), chiefly because of the enlargement of their lumen. Whereas in the former stages the openings were lying rather afar, now their terminal portions have been "pushed nearer" medially. Consequently, the ducts empty close to each other on both sides of the single, now abortive, Müllerian duct, into the median portion of the dorsal wall of the sinus, that forms a distinct bud of the colliculus seminalis (Fig. $54 \mathrm{~W}$ ).

The Wolffian ducts, in the embryonic stages just described, do not show any differentiation into portions characteristic of the ductus deferens in young and sexually mature males. Glandulae ampullarum (by analogy with other Mammals) are supposed to be formed as late as in the moment of birth.

\section{Juvenile stage}

The differentiation of the ductus deferens into three distinct portions characterized by a different microscopic structure, which has been described in sexually mature males, appears in a six-week old individual.

The proximal swelling, although not perceived by a naked eye, appears as a slight distention of the lumen of the duct which gives some lateral diverticula. The epithelium is low, single-layered, the stereocilia are not developed yet. The distal swelling (gl. ampullarum) hardly seen macroscopically has circa $300 \mu$ in diameter. The above gland is in a stage of distinct growth and differentiation. The central canal lined with a low single-layered epithelium (the cells poor in cytoplasm have large nuclei) branches into small tubules with narrow often tightened iumen which are growing irto the surrounding connective tissue. The tubules are built of the same undifferentiated single-layered epithelium as the central canal. The separate tubules are kept apart by quite a large amount of connective tissue. The whole is surrounded by a well differentiated muscular layer (Fig. 14).

\section{Glandulae prostaticae}

\section{A. Sexually mature male}

The glandulae prostaticae are tubulo-alveolar glands with a lobular structure (Fig. 15). The cone-shaped lobules, have frequently bulged bases which are directed towards the surface giving the gland a clotty appearance. The gland is surrounded by a connective tissue capsule which contains the bands of smooth muscle fibers. These last penetrate 
into the substance of the gland and surround the particular lobules. The lobules are separated by a relatively large amount of connective tissue rich in elastic fibers, blood vessels and single smooth muscle cells. Within the lobules, however, the arrangement of tubes is compact. The efferent tubes of the separate lobules fuse to form ducts with an increasing diameter which empty into the main excretory duct. The excretory alveolae are built of a single-layered prismatic or isoprismatic epithelium. (in the alveolae distended with secretion, i. e. at the resting phase, the epithelium is as a rule, low and isoprismatic). The round, oval or irregularly shaped nuclei placed always in the basal portion of the cell are highly basophilous. The cytoplasm has a small number of vacuolae and numerous minute granules staining intensly with cosin (Fig. 17). The secretion seems to be apocrine and eccrine, this latter being more common, since in many cases I observed the nubbles or bands of secretion issued from the apical pole of the cell, whereas the detachment of larger portions of cytoplasm has been only sporadically observed. The secretion deposited in the lumen of tubes can be coarse-grained, fine-grained or almost homogeneous. The first two kinds of secretion are staining red by Heidenhain's "Azan" method, while this last stains blue. Since the excretory duct of the gland contains usually a homogeneous secretion, it seems to be a definite product of secretion. The excretory duct of the gland is built of a single-layered prismatic epithelium thrown into longitudinal folds. The exterior part of the gland is coated by a thin layer of connective tissue and a layer of smooth muscle fibers disposed circularly. Both left and right ducts enter the dorsal wall of the urethra laterally to the vasa deferentia, coursing up to the openings on the colliculus seminalis (see chapter: Urethra, p. 83).

\section{B. Emioryonic development}

Stage I (the embryos 8.5 and $8.6 \mathrm{~mm}$ long). The presence of the prostatic glands buds has not been stated.

Stage II (The embryos 10.8 and $11.6 \mathrm{~mm}$ long). Immediately beyond the openings of the Wolffian ducts there are two small epithelial buds which, growing from the lateral walls of the sinus urogenitalis, are directed aside (one on each side at a time). In this stage they are scarcely $37 \mu$ long. The buds are built of light polygonal epithelial cells of the sinus, bordered by dark staining cells disposed vertically to their surface, these last being continuous with the edging "dark" cells of the wall of sinus urogenitalis.

Stage III (The embryos 14.2 and $14.5 \mathrm{~mm}$ long). The buds are about $50 u$ long. No other change in their structure has been observed. They 
have not grown yet beyond the musculus urethralis which is now differentiating around the canal (Fig. 21). The mesenchyme surrounding the buds is disposed circularly.

\section{Juvenile stage}

Being harcly perceived with a naked eye the prostatic glands approach the definite shape. They have a form of irregular lobes lying dorsally to the urethra. In their interior structure a distinct division into lobules is already marked. The interlobular connective tissue is deficient in elastic fibers characteristic of a fully grown gland, it has instead much more cellular elements. Each lobule consists of a system of branching tubules built of non-differentiated, isoprismatic epithelium with large nuclei lying centrally, and a small amount of cytoplasm. The terminal branches are usually firmly tightened. In the lumina of larger tubules I could sometimes see a flocculent secretion and single detached cells It seems that both the differentiation of the glandular epithelium and the rapid growth of the gland do not occure earlier as at time of puberty (February-March in the next year after the birth).

\section{Urethra}

\section{^. Sexually mature male}

Pars prostatica urethrae (the regions: crista urethralıs and colliculus seminalis) The gradually distending urinary bladder neck passes into the urethra. As early as at the end of collum vesicae there appear laterally the first bands of a striated $m$. urethrulis. The epithelial canal of the neck is surrounded by a layer of smooth muscle fibers continuous with smooth muscle of the prostata and the vas deferens. The terminal portions of the deferent duct adhere the neck dorsally, while the ducts and tubes of the prostatic gland are disposed laterally. Somewhat farther caudally, the bands of $m$. urethralis surround semi-circularly the urethra at its dorsal and lateral sides. Finally, they coat the urethra together with ducts in a common capsule consisting of circularly and obliquely disposed fibers. This is the beginning of the crista urethralis. The canal of the urethra with walls thrown into extraordinary series of longitudinal folds, is lined with a striated ( $2-3$ layers) cuboidal epithelium in which single intraepithelial tubules are not infrequent. There are particularly well marked two dorsal grooves which approaching the colliculus seminalis are deeper and deeper. The canal is surrounded by a fairly thick layer of connective tissue not strongly drained by blood vessels, and entirely dificient in smooth muscle elements occurring in a level with urinary bladder neck. The 
deferent ducts placed dorsally to the epithelial canal of the urethra run paralelly to it while the ducts of the prostatic glands (one at each side at a time) course laterally to the deferent ducts. Each duct is surrounded by its own connective-tissue capsule (Fig. 25 a, b). The nearer the colliculus seminalis the narrower is the diameter of the urethra. The urethra changes its shape, which being previously slightly flattened dorso-ventrally is now cylindrical. The mentioned above, grooves become more and more divergent increasing the width of the enclosed dorsal fold. The vasa deferentia gradually approach the dorsal wall of the epithelial canal of the urethra, coursing within the dorsal fold, they subsequently turn at right angle reach its apex and empty into the urethra (Fig. 26 a). The prostatic glands ducts are emptying at almost the same level, laterally to the dorsal grooves (Fig. $26 \mathrm{~b}$ ).

The prostatic part of the urethra is about $2.5 \mathrm{~mm}$ long. Within this portion of the urethra the presence of gl. urethrales has not been stated.

Pars membranacca urethrae (pars muscularis). This portion of the urethra enclosed between the openings of vasa deferentia and the openings of gl. bulbo-urethrales ducts is not to be distinguished morphologically, the cranial end of $m$. bulbo-cavernosus which covers the bulbus penis being adherent to the region of colliculus seminalis. It can be, however, distinguished considering its microscopical structure. This portion of the urethra is about $1.5 \mathrm{~mm}$ long. While becoming more distant to the colliculus seminalis the diameter of the urethra gradually decreases. This is due to the tapering of the epithelial canal as well as to the thinning of $m$. urethralis. This latter terminates dorsally at a distance circa $700 \mu$, and ventrally at about $400 \mu$, before the openings of gl. bulbo-urethrales ducts. The longitudinal folds seen in the initial portion of the striated, prismatic epithelium of the canal, gradually disappear, so that the lumen of the canal in farther portions is regularly elliptic. Small intra-epithelial tubules occurring in the pars prostatica are also fairly frequent in this portion of the urethra. Sometimes, they are single tubes branched off from the epithelium of the urethra, showing however, no secretion ability, they do not resemble the gl. urethrales at all (Fig. 36).

Bulbus penis and sinus urethrae bulbi. A well-developed bulb of the spongy portion of the penis appears at the site where the pars membranacea urethrae passes into the pars spongiosa. The bulb covered with $m$. bulbo-cavernosus is called the bulbus penis. The canalis urogenitalis makes there an arc bulged dorso-caudally (the same is direction of the bulbus penis). The cranial part of this arc is made by the pars membranacea urethrae, the caudal one being constituted by the initial portion of the pars spongiosa (Fig. $39 \mathrm{p}, \mathrm{s}$ ). On the boundary of 
those two portions, thus in the middle of the arc the canal branches into a large diverticulum blind cranially. This diverticulum is $1.2 \mathrm{~mm}$ long, about $1.2 \mathrm{~mm}$ deep (dorso-ventrally) and circa $1 \mathrm{~mm}$ wide (the maximum width). This is the sinus urethrae bulbi which is exceptionally large in Common Shrew (Fig. $39 \mathrm{~h}$ ). The sinus is lined with a striated prismatic epithelium, identical with the epithelium of the urethra, and filled with secretion, which can be also found in the urethra. The sinus lies entirely within the bulbus penis (Fig. $39 \mathrm{n}$ ). The ducts of gl. bulbourethrales course within the wall separating the cranial part of the sinus from the membraneous part of the urethra. The ducts empty into the urethra at the apex of the wall.

\section{B. Embryonic development}

In the embryo $11 \mathrm{~mm}$ long the urethra sensu stricto is still very short (the distance between the openings of the ureters and of such of the Wolffian ducts does not exceed $120 \mu$ ), it courses cranio-caudally. Within the distance of some scores microns beyond the openings of the Wolffian ducts the sinus urogenitalis keeps the same direction, thereupon it makes an arc and courses ventralwards, at the same time its lumen gradually tapers. In the middle of this last portion, i. e. in the region between the pars pelvina and pars phallica the canal becomes distended again. At its terminal portion the canal is thinning and comes out at the basis of the tuberculum genitale. The distended part of the canal at the side where the pars pelvina passes into pars phallica is undoubtly the inception of the sinus urethrae bulbi (Fig. $52 \mathrm{~h}$ ). Here the buds of $g l$. bulbo-urethrales take their origin, and in a fully grown animal the ducts of those glands are emptying.

In the embryos 14.2 and $14.5 \mathrm{~mm}$ long, in a level with the Wolffian ducts, the lumen of the sinus is continuous with two dorsal grooves which enclose an oblong fold of the dorsal wall, this last being the bud of the colliculus seminalis (Fig. 54). In all embryos the epithelium of the canal is striated ( $2-3$ layers), built of large, polygonal cells with feebly staining nuclei lying centrally. Only the outermost part constists of smaller prismatic cells with oval strongly basophilous nuclei. These cells are the so-called "dark" bordering cells of the sinus urogenitalis epithelium (Fig. 54). The epithelial canal is surrounded by circularly disposed mesenchyme; in its external portions one sees differentiating fibers of $m$. urethralis.

\section{Juvenile stage}

The entire urethra is allready definitely developed. Its separate portions do not differ essentially in their anatomical and histological 
structure from those occurring in a fully grown male. The dorso-ventral flattening of the urethra is better pronounced than in a fully grown male, and the walls of the sinus urethrae bulbi are greatly folded (Fig. $43 \mathrm{~h}$ ). Both phenomena are probably due to the lack of secretion, which in the mature male keeps the walls in stress.

\section{Gl. bulbo-urethrales (s. Cowperi)}

\section{A. Sexually mature male}

Gl. bulbo-urethrales are tubulo-alveolar compound glands. Their structure is exceptionally tight (Fig. 45). The gland is surrounded by i coat of striated muscle with longitudinally and (in some portions) circularly disposed fibers. This muscular sheath is, however, not uniform. Its width being dependent on the given part of the gland, reach sometimes $350 \mu$. A layer of connective tissue which lies under the muscular sheath forms a fibrous capsule adjacent to the surface of the gland, and delicate trabeculae penetrating into the substance of this gland. The connective tissue in both sheath and trabeculae is deficient in muscular elements, but contains instead numerous minute blood vessels. The substance of the gland is mainly composed of alveolae varying in shape and diameter, and of tubes, whose diameter ranges from $8 \mu$ (small tubes) to almost $40 \mu$ (relatively large excretory tubes) which empty into the central cavity of the gland. The alveolae are built of fairly big cells tapering apically, with oval or round nuclei, which being placed in the basement of cells, lie on the peryphery of the alveolum (Fig. 48). The cytoplasm stains feebly with eosin and has a distinct fine-grained structure. The lumen of the alveolae is usually strongly tightened, almost invisible. The epithelium lining the tubes is, however, isoprismatic with relatively large nuclei disposed centrally. The cytoplasm is highly eosinophilous. The lumen is distinctly opened (Fig. 48). The interior of the gland is taken by a large cavity which continues throughout its whole length. It makes numerous irregular sinuses and branches. The cavity is lined with isoprismatic epithelium, similar to that of the tubes. It seems that the alveolae are the chief producers of secretion excreted by the gland, because of the granular structure of the cytoplasm found in their cells. Since, however, the alveolae have no lumen, it is difficult to establish the kind of secretion. Nevertheless, there are some reasons to suppose that the epithelium of efferent tubes as well as the epithelium lining the central cavity are able to produce secretion in apocrine manner. The lumen of the central cavity is usually filled with fine-grained or flaky secretion staining very feebly (Fig. 45). 
Within the proximal median portion of the gland, the central cavity becomes distinctly narrow and passes directly into a long excretory duct. This last penetrates between $m$. ischio-cavernosus and $m$. bulbo-cavernosus, thereupon it changes its direction, coursing cranialwards to the cranial end of $m$. bulbo-cavernosus, then it turns caudally again running between the $m$. bulbo-cavernosus and the $m$. urethralis, parallely to the urethra. In their terminal portion the ducts course within a wall separating the cranial part of the sinus urethrae bulbi from the urethra and empty into the sinus at the end of the wall (see: Urethra, p. 83).

The ducts are built of a single-layered prismatic epithelium. Only in their terminal part the epithelium is identical with a stratified prismatic epithelium of the urethra. Troughout their length (except the terminal part) the ducts are associated with a glandular tissue which here and there forms some miniature glands similar to the bulbo-urethral glands. One of such glands, placed immediately before the entrance of the ducts into the wall of the sinus is shown on Fig. 38. Its tubulo-alveolar structure and its short excretory duct are well seen (Fig. $38 \mathrm{v}$ ). In reality, however, the duct empties into the left duct of the gl. bulbo-urethrales somewhat farther caudally.

\section{B. Embryonic development}

Stage I (The embryos 8.5 and $8.6 \mathrm{~mm}$ long). The buds of gl. bulbo-urethrales are not present yet.

Stage II (The embryos 10.8 and $11.6 \mathrm{~mm}$ long). In a level with the blastema of the bulbus penis, thus in site where the pars pelvina of the sinus urogenitalis passes into the pars phallica two solid epithelial buds grow from the dorso-lateral walls of the sinus. The buds directed cranially and dorsally are built of the "light" cells of the epithelium of the canal and are bordered by small, easier staining cells, disposed vertically to the surface of the bud. In this stage the buds do not reach their blastema yet; these last are already formed and lie at both sides of the intestine.

Stage III (The embryos 14.2 and $14.5 \mathrm{~mm}$ long). The buds are larger if compared with the former stage. One may distinguish: (1) a narrowed basal portion of the bud (circa $40 \mu$ in diameter), its one part joins sinus urogenitalis, while the other one is growing into the blastema (situated at the ventro-lateral surface of the intestine) (Fig. 50), and (2) a slightly distended distal portion (the diameter about $75 \mu$ ) lying within the blastema. The substance and the duct of the gland will be latter differentiated from the distal and basal portions of the bud, respectively. The buds are lumenless within their entire length. 


\section{Juvenile stage}

Although the gl. bulbo-urethrales are only about $1 \mathrm{~mm}$ long nevertheless their shape and localization are, however, almost the same as in an adult male. The gland is surrounded by a relatively thick connective tissue sheath and a well developed layer of striated muscle. The substance of the gland consists of a system of exceedingly ramified tubules built of an isoprismatic, non-differentiated epithelium. Such epithelium is also typical for other accessory glands of the same stage (gl. prostaticae, gl. ampullarum). The tubules are sticking in a mass of connective tissue which still constitutes a very important element of the substance of the gland (Fig. 47).

\section{Müllerian duct (utriculus prostaticus)}

These structures being completely absent in both young and sexually mature males, they probably disappear at the moment of birth or immediately before. This may be infered from the velocity of their regression observed in the embryos.

Stage I (The embryos 8.5 and $8.6 \mathrm{~mm}$ long). The Müllerian ducts are less developed than the Wolffian ones, though throughout their entire length they are still paired. Because of the temporary fusion of both ducts occurring in their terminal portion, the ducts are H-shaped in cross section (Fig. $53 \mathrm{~m}$ ).

Stage II (The embryos 10.8 and $11.6 \mathrm{~mm}$ long). The Müllerian ducts are discontinuous within the plicae genitales. In farther caudal portions lying within the funiculus genitalis, the ducts become fused into one a single duct, whose diameter is smaller than the diameter of a single Wolffian duct.

Stage III (The embryos 14.2 and $14.5 \mathrm{~mm}$ long). Within the plicae genitales the Müllerian ducts have completely disappeared. The single duct within the funiculus genitalis is reduced to a solid string of cells (3-4 cells on a cross-section) having $10 \mu$ in diameter. Only within a short distance (about $35 \mu$ ) before the duct comes in contact with the dorsal wall of the sinus urogenitalis, it keeps a character of an epithelial canaliculus with a reduced lumen, thus it deserves to be termed the utriculus prostaticus (Fig. $54 \mathrm{~m}$ ). It penetrates into the epithelium of the dorsal wall of the sinus urogenitalis between the Wolffian ducts, on the level with their openings.

\section{B. SOREX MINUTUS LIN N A E U S, 1776}

1. Morphology of the male reproductive system

The structure of the male genital system in Lesser Shrew is almost identical with that of Common Shrew, which has been described above. 
This resemblance has been emphasized by B r a m bell (1936 a, b) who described the male reproductive system in this species.

A detailed analysis however, has allowed to detect some differences between both species. These will be described in the sequel.

\section{Vas deferens (Wolffian duct)}

\section{A. Sexually mature male}

The three portions of the deferent duct which have been distinguished in Common Shrew may be also found in Lesser Shrew (See p. 78). Their microscopic structure does not differ essentially, either. The few differences, that have been stated, are of a not great importance. E. g. pseudostratified (double rowed) epithelium lining the lumen of the proximal swelling consists of isoprismatic rather than prismatic cells. The nuclei are relatively large and placed centrally. The stereocilia growing from the apical portions of the cells are thicker and more densly arranged (cf. Figs. 8 and 7). The secretion ability of this epithelium seems to be greater than in Common Shrew. The cells with club-like apical portions, resembling thus the glandular cells of the gl. ampullarum, are rather often observed. In the lumen of the canal one often sees the fragments of a coagulated homogeneous secretion mixed with spermatozoa. The clistal swelling (gl.ampullarum) consists of a system of tubes and pockets placed within the wall of the ductus deferens and emptying into the central canal, this last being continuous with the lumen of the proximal portion of the ductus deferens. The above pockets in Lesser Shrew are separated by a relatively large amount of connective tissue making their arrangement less tight. The wall of the central canal, usually thrown into logitudinal folds, is lined with a prismatic glandular epithelium, in which the ciliated cells are not infrequent. The ciliated cells are also cbserved among the glandular cells lining the pockets. Besides the just described differences, the above epithelium does not differ from the ampullar epithelium in Common Shrew. The secretion is apocrine and eccrine. The spermatozoa are observed, as a rule, in the lumen of the central canal, and sporadically, in the pockets. The gl. ampullarum are terminated distally in a level with the crista urethralis.

\section{B. Embryonic development}

In the embryo $13 \mathrm{~mm}$ long (the oldest stage which was at my disposal) the buds of gl. ampullarum are not seen yet on the Wolffian ducts.

$$
\text { C. Juvenile stage }
$$

In this stage the deferent duct is developed to the same extent as in 
the young male of Common Shrew; the same analogy being found in its microscopic structure.

\section{Glandulae prostaticae}

\section{A. Sexually mature male}

Position of this glands (dorsal with respect to the urinary bladder and urethra), their external appearance (clotty structure) as well as the microscopic structure (a compound tubulo-alveolar gland) make them identical with prostatic glands of Common Shrew. There are, however, some differences in their microscopic structure, as well as in the number of their excretory ducts.

Both the alveolae and the glandular tubes are built of an isoprismatic epithelium with highly basophilous nuclei placed in the basement of cells (Fig. 19). The cytoplasm is filled with eosinophilous granules and, as a rule, is much vacuolized (the vacuolae present in glandular cytoplasm of the gl.prostatica in S. araneus were neither so frequent and large). The secretion is as a rule apocrine or eccrine, but a holocrine secretion has been also observed. (The entire cells containing nuclei and destroyed fragments of glandular epithelium have been found in the lumen of the alveolae). This last way of secretion has not been observed in Common Shrew.

Whereas in $S$. araneus the excretory tubes of the lobules are always emptying into a single ductus excretorius, in $S$. minutus the number of excretory ducts is variable. Most often they appear in number of two ducts on each side at a time, in some cases, however, they may be more numerous, eg. two and three or even three and four (cf. p. 92). I did not state any difference in the structure of the epithelium lining those ducts. They all are built of a single-layered prismatic epithelium, resembling the glandular epithelium of the alveolae, which within a short terminal distances passes into the "urethral" epithelium of the urethra.

\section{B. Embryonic development}

It has been stated that in development of the gl. prostaticae in Lesser Shrew more than one pair of buds is present (In Common Shrew there is always one pair only.

Stage I (The embryos 8.0, 8.2, 9.1 and $10.5 \mathrm{~mm}$ long). In the first three embryos no buds of gl. prostaticae have been stated yet, whereas in the longest embryo $(10.5 \mathrm{~mm})$ one pair of such buds have been found. They have been defined as lateral buds of the gl. prostatica. The above embryo has been cut into a series of sagittal sections. 
Stage II (The embryo $11.5 \mathrm{~mm}$ long). The described above pair of lateral buds of $\mathrm{gl}$. prostaticae occurs in this stage in form of distinct epithelia! buds, growing from the lateral walls of the sinus urogenitalis, one at each side at a time. The buds are circa $60 u$ long. Besides them, there is also a second pair of buds, which grow from the ventro-lateral walls of the sinus. They are situated at the distance 20-30 $u$ cranialwards, immediately beyond the entrance of the Wolffian ducts into the sinus urogenitalis. They are very small, solid epithelial buds, merely about $30 \mu$ long.

Stage III (The embryo $13 \mathrm{~mm}$ long). In this embryo I have stated the presence of 3 pairs of the buds of gl. prostaticae. In addition to the two just described, there is one pair more of buds (ventro-lateral) (Fig. 23). They all are solid epithelial buds. The buds of first and third pairs (ventro-lateral) grow 30-40 $\mu$ deep inside the mesenchyme, whereas, the lateral buds have almost doubled their length compared with the former stage. They are now almost $120 \mu$ long. These buds are solid, club-shaped structures lying within the differentiating $m$. urethralis. A minute gemma which initiates a secondary branching grows dorsally from the distal part of the bud (Fig. 23).

The number of embryos being at my disposal did not allow me to establish the most frequent quantity of the buds. I was, however, able to draw some conclusions from studies carried out on the glands and their ducts in fully grown males.

\section{Juvenile stage}

Microscopic structure of the gl. prostaticae is similar to that in the male of Common Shrew.

\section{Urethra}

\section{A. Sexually mature male}

Since in Lesser Shrew we deal with a greater number of $g l$. prostaticae ducts, the anatomical structure of pars prostatica urethrae is somewhat different if compared with the Common Shrew. Histological structure, however, is almost identical. The mucous membrane of the canal has neither crypts nor tubes which could be considered as urethral glands. One detail, however, deserves to be mentioned. Within connective tissue surrounding the epithelial canal, more or less in the middle of the pars prostatica urethrae, there are numerous sinuses filled with blood cells. Eventually, this tissue in the region of colliculus seminalis looks almost alike with spongy part of the wrethra. In the other Shrews this phenomenon has not been observed. 
Basing my observations on serial sections of the urethra, taken from eight males (5 microscopic and 3 binocular series) I have stated that most frequently the number of gl. prostaticae ducts in $S$. minutus is four: two on the left and two on the right sides. This number has been found in 4 cases, in the remaining 4 cases this number was different (Cf. Table 2 and Figs. 31 and $32 d$ ).

The arrangement of the gl. prostaticae ducts and vasa deferentia on crista urethralis is the following (Figs. 28 and 31 ). The vasa deferentia are always lying dorsally to the urethra. The same constant position is assumed by the pair of prostatic glands ducts which have the greatest diameter. In all investigated males these ducts lie dorso-laterally to the

Table 2.

Number of the ducts of $\mathrm{gl}$. prostaticae in S. minutus.

\begin{tabular}{|c|c|c|c|c|c|c|c|c|c|c|c|}
\hline \multirow{2}{*}{$\begin{array}{c}\text { Consecutive } \\
\text { number of the } \\
\text { male }\end{array}$} & \multicolumn{2}{|c|}{$\begin{array}{l}\text { Total num- } \\
\text { ber of ducts } \\
\text { of gl. pro- } \\
\text { staticae }\end{array}$} & \multicolumn{2}{|c|}{$\begin{array}{l}\text { Number } \\
\text { of dorsal } \\
\text { ducts }\end{array}$} & \multicolumn{2}{|c|}{$\begin{array}{c}\text { Number of } \\
\text { the openings } \\
\text { of dorsal } \\
\text { ducts }\end{array}$} & \multicolumn{2}{|c|}{$\begin{array}{l}\text { Number of } \\
\text { lateral and } \\
\text { dorso-late- } \\
\text { ral ducts }\end{array}$} & \multicolumn{2}{|c|}{$\begin{array}{l}\text { Number of } \\
\text { openings of } \\
\text { dorso-late- } \\
\text { ral and late- } \\
\text { ral ducts } \\
\end{array}$} & \multirow[t]{2}{*}{ Remarks } \\
\hline & $\begin{array}{l}\text { left } \\
\text { side }\end{array}$ & $\underset{\text { side }}{\text { right }}$ & $\begin{array}{l}\text { left } \\
\text { side }\end{array}$ & $\begin{array}{l}\text { right } \\
\text { side }\end{array}$ & $\begin{array}{l}\text { left } \\
\text { side }\end{array}$ & $\underset{\text { side }}{\text { right }}$ & $\begin{array}{l}\text { left } \\
\text { side }\end{array}$ & $\begin{array}{l}\text { right } \\
\text { side }\end{array}$ & \begin{tabular}{|l|} 
left \\
side
\end{tabular} & $\begin{array}{l}\text { right } \\
\text { side }\end{array}$ & \\
\hline young male & 3 & 2 & 1 & 1 & 1 & 1 & 2 & 1 & 2 & 1 & $\begin{array}{c}\text { Microscopic } \\
\text { series }\end{array}$ \\
\hline mature male $\mathrm{A}$ & 3 & 4 & 1 & 1 & 1 & 1 & 2 & 3 & 3 & 4 & " \\
\hline mature male $B$ & 2 & 2 & 1 & 1 & 1 & 1 & 1 & 1 & 1 & 2 & , \\
\hline mature male $\mathrm{C}$ & 2 & 2 & 1 & 1 & 1 & 1 & 1 & 1 & 1 & 1 & $"$ \\
\hline mature male $\mathrm{D}$ & 2 & 3 & 1 & 1 & 1 & 1 & 1 & 2 & 1 & 2 & " \\
\hline mature male $E$ & 2 & 3 & 1 & 1 & 1 & 1 & 1 & 2 & 1 & 2 & $\begin{array}{l}\text { binocular } \\
\text { series }\end{array}$ \\
\hline mature male $F$ & 2 & 2 & 1 & 1 & 1 & 1 & 1 & 1 & 1 & 1 & $"$ \\
\hline mature male $\mathrm{G}$ & 2 & 2 & 1 & 1 & 1 & 1 & 1 & 1 & 1 & 1 & $"$ \\
\hline
\end{tabular}

vasa deferentia and dorsally to the epithelial duct of the urethra (Figs. 28 and 31 b). They are always single paired ducts emptying by two openings into the urethra. Since their terminal portions may branch (it has been stated in two cases) the eventual number of their opening into the urethra can be greater (Cf. Table 2 and Figs. 31, 32 d).

Within colliculus seminalis the lumen of the urethra is semilunar, its convexity being directed ventrally. Two deep grooves delimit the median eminence of its dorsal wall which bulges into lumen in form of a longitudinal fold. Similar, though somewhat narrower, dorsal folds continue laterally to the median fold, separated from it by the mentioned dorsal grooves, and laterally bordered by the dorso-lateral horns of the urethral lumen. When the canal is tightly filled with secretion its 
walls become stretched and the folds almost disappear (Cf. Figs. 30 and 32 ).

The dorso-lateral and lateral ducts of the prostatic glands open into the urethra most cranially (Fig. $32 \mathrm{~d}$ ). Their openings lie either on the apex of dorsal folds, laterally to the dorsal grooves, or in lateral walls of the urethra. Nearly at the same level, but somewhat farther caudally, are the openings of vasa deferentia and of dorsal ducts of gl. prostaticue. Vasa deferentia are emptying into the urethra on the apex of the median fold, whereas the prostatic gland ducts open on the top of dorsal folds or into dorsal grooves (Fig. $30 \mathrm{a}, \mathrm{b}$ ).

Pars membranacea urethrae (pars muscularis). This portion of the urethra, like in S. araneus, can be distinguished because of its microscopic structure. It is ca. $1.3 \mathrm{~mm}$ long. The diameter of the epithelial canal of the urethra at first gradually decreases, but in a level with cranial end of the sinus urethrae bulbi the canal is rapidly narrowed (Fig. 41 p). The epithelium lining the urethra is continuous with a stratified prismatic epithelium of the pars prostatica. Numerous sinuses filled with blood cells are still present in the connective tissue surrounding the epithelial canal. The tissue passes caudally in to the corpus spongiosum surrounding the sinus. The $m$. urethralis ends dorsally at a distance about $800 \mu$, and ventrally at about $530 \mu$ before the openings of gl. bulbo-urethrales ducts into the urethra. In the epithelium of the urethra neither gl. urethrales nor crypts nor alveolae have been found.

Bulbus penis et sinus urethrae bulbi seem to be developed somewhat better than in $S$. araneus (considering their respective dimensions). Somewhat different, however, is the course of the urogenital canal within this portion, (the arcuated bending is somewhat less pronounced) and consequently, the orientation of the sinus urethrae bulbi is different too (Cf. Figs. 41 and 39). The sinus which ends blindly cranialwards is dorsally bulged, it gradually narrows caudally and passes into pars spongiosa urethrae. Eventually, it is shallower $(0.8 \mathrm{~mm})$ but decisively longer (about $2 \mathrm{~mm}$ ) if compared with the corresponding dimensions, $(1.1 \mathrm{~mm}$ and $1.2 \mathrm{~mm}$, respectively) of the sinus in $S$. araneus. The walls surrounded by the corpus spongiosum urethrae are lined with a stratified prismatic epithelium. The gl. bulbo-urethrales ducts empty (like in Common Shrew) into the sinus at the end of the wall separating its cranial part from the urethra, thus more or less, in the middle of its length (Fig. $41 \mathrm{k}$ ).

\section{B. Emibryonic development}

The course of the canalis urogenitalis and its histological struclure are the same as in $S$. araneus. 
Anatomical structure of the juvenile urethra is almost the same as in a sexually mature male.

\section{Glandulat bulbo-urethrales (s. Cowperi)}

A. Sexually mature male

The localization of the glands, their shape and microscopic structure and their connections with ducts in juvenile and mature males are similar as in $S$. araneus.

\section{B. Embryonic development}

The buds of gl. bulbo-urethrales are formed in the same manner as in $S$. araneus.

Stage I (The embryos 8.0 and $8.2 \mathrm{~mm}$ long). Minute epithelial buds, grownig one at a time on each side of the dorso-lateral walls of the sinus urogenitalis, appear at the site where the sinus passes from the pelvical part into the cavernous one.

Stage II (The embryo $9.1 \mathrm{~mm}$ long). The buds are somewhat larger and have a club-like shape.

Stage III (The embryo $11.5 \mathrm{~mm}$ long). The buds reach the lateral walls of the intestine. They are about $110 \mu$ long.

Stage IV (The embryo $13 \mathrm{~mm}$ long). No stanges in the structure, besides further growth of the buds, have been stated. The buds are solid, lumenless. The diameter of club-shaped part is $80 \mu$, the buds are about $170 \mu$ long.

\section{Müllerian duct (utriculus prostaticus)}

There are no remnants of these structures either in sexually mature or in young males. Their regression taking place during the embryonic development is the following:

Stage I (The embryos 8.0 and $8.2 \mathrm{~mm}$ long). The Müllerian ducts in their cranial portion (within the plicae genitales) are still well developed, although their diameter is somewhat smaller than the diameter of the Wolffian ducts. After having entered the funiculus geritalis, the medial walls of both Müllerian ducts become fused and form one duct with a double lumen. Within a short distance, immediately before reaching the dorsal wall of the sinus urogenitalis, the ducts remain double. Each of the branches adhering the median walls of the Wolffian ducts, is joined with the epithelium of the dorsal wall of the sinus.

Stage II (The embryo $9.1 \mathrm{~mm}$ long). Within the plicae genitales the Müllerian ducts are still continuous, but their diameter is reduced and the lumen is tightened. Within the funiculus genitalis the duct is single, 
but its lumen contains the remnants of the septa which had divided the lumina of both ducts.

Stage III (The embryo $11.5 \mathrm{~mm}$ long). One observes a strong regression of the Müllerian ducts. Both in plicae genitales and funiculus genitalis the only evidence of their presence is given by a solid string of cells (3-4 on a cross section) surrounded by circularly disposed mesenchyme. A canaliculus with a distinct lumen remains only in terminal portion adjoining the dorsal wall of the sinus urogenitalis. The canaliculus is about $50 \mu$ long and lies between the Wolffian ducts.

Stage IV (The embryo $13 \mathrm{~mm}$ long). A string of circularly disposed stroma appearing in the site of original Müllerian ducts is their only remnant. Only the distal, mentioned above, part of the ducts remains in form of a blind at the beginning canaliculus, which in a level with Wolffian ducts, joins the epithelium of the sinus urogenitalis. This structure deserves the term utriculus prostaticus (Fig. $55 \mathrm{~m}$ ).

\section{NEOMYS FODIENS (P E N A N T, 1771)}

1. Morphology of the male reproductive system

The male reproductive system in $N$. fodiens has been described by $\mathrm{K}$ a u dern (1911), its interpretation, however, has not been correct being based on only one individual (See Discussion). A rough description of this system can be found in paper by Price (1953).

The testes whose average dimensions are $10 \mathrm{~mm} \times 7 \mathrm{~mm}$ lie in the cremaster sacs (a constant position). The typically-developed epididymis adheres the median surface of the testes. The ductus deferens issued from the epididymis is within its proximal portion pursuing an extremely convoluted course, farther along it passes into very well developed distal swelling ( $g l$. ampullarum). Gl. ampullarum are long roller-shaped arcuated structures which enclose the gl. prostaticae cranially and laterally (Fig. 3 a). Their proximal portion being the widest, (circa $3.5 \mathrm{~mm}$ in diameter) the gl. ampullarum become gradually narrowed approaching the dorsal wall of the urethra, where their diameter is about $1.8 \mathrm{~mm}$.

The gl. prostaticae lie dorso-laterally to the urinary bladder (Fig. 3, p). They form two compact irregularly shaped lobes with a rather smosth surface (unlike the distinctly clotted surface observed in gen. Sorex).

The pair of glands lying on both sides of the root of the tail, dorsally to the bulbus penis, because of their position, structure and development, should be considered as gl. bulbo-urethrales. (So far the position of those glands in the systematics of the accessory glands has not been established, (see Discussion). Their shape is more or less spherical, slightly 
flattened dorso-ventrally. Their dimensions are $3.2 \mathrm{~mm} \times 2.6 \mathrm{~mm}$ (Fig. 3 c).

The urinary bladder passes dorsally into the urethra, which within its pelvical part is uniformly swollen. The penis, begins with wide crura penis in a level with the bulbus penis. Its proximal portion is directed cranially further along the penis turns caudally. The penis is thicker and shorter than in gen. Sorex. Since the vagina in Neomys fodien. females is also shorter than in other shrews, these two phenomena may be closely related ( $\mathrm{Price}$ 1953). The top of the penis is provided with cärtilagineous processes which are absent in gen. Sorex.

\section{Vas deferens (Wolffian duct)}

\section{A. Sexually mature male}

The proximal portion of the ductus deferens, which in Common and lesser Shrews forms a spindle-like swelling immediately after leaving the epididymis, in Water Shrew is uniformly thick throughout its whole length. This portion of the ductus deferens is convoluted, numerous loops are surrounded by a vascular connective tissue. On longitudinal sections made through this region one can well see (Fig. 4) the separatc sections of the canal provided with thẹir own muscular walls. The histological structure of this portion of the ductus deferens (Fig. 5) is the following: The canal is lined with a pseudostratified epithelium composed of low basement cells and of prismatic surface cells equipped with stereocilia. The canal is surrounded by a thin layer of connective tissue and by a well developed muscular membrane with fibers disposed in typical manner. In the lurnen of the canal, besides the spermatozoa, one observes some droplets of flakes of secretion proving the secretory activity of the epithelium. Immediately before the duct passes into the distal swelling, the lumen of the canal is branched (because of numerous diverticula occurring in the epithelium) and the secretory activity of the cells is also more intense.

The distal swelling of the deferent duct (gl. ampullarum). The passage of the ductus deferens into the distal swelling is rather rapid. At the beginning its diameter is about $1 \mathrm{~mm}$ (the diameter of the proximal portion of the ductus deferens is about $400 \mu$ ), but somewhat farther it amounts to circa $2.5 \mathrm{~mm}$. The microscopic structure of the swelling is almost the same as in gen. Sorex. The swelling is a true gl. ampullarum (c.f. Figs. 10 and 11). The central canal is lined with an isoprismatic, ciliated epithelium (unlike the Sorex studied this character is constant), which is secretory active. The ciliated cells are also found in the pockets adjacent the central canal. The amount of connective 
tissue within the gland being rather scarce, the arrangement of the pockets is rather compact. The glandular epithelium is single-layered, prismatic or isoprismatic but always regular (unlike plug-like bulged or club-shaped glandular cells observed in gen. Sorex) (Cf. Figs. 12 and 13). Binucleated cells are frequently observed. The eccrine secretion prevails, although the apocrine secretion takes also place. The secretion is collected in the apical portion of the cell (this portion is highly basophilous) and subsequently discharged into the lumen of the pocket in form of clots or bands (Fig. 13). Like in Common and Lesser Shrews the spermatozoa may be sometimes seen within the gland. The $g l$. ampullarum course through the wall of the ductus deferens continuing up to the level with crista urethralis. Nearly the very openings the epithelium is provided with cilia. Within a very short terminal portion, the epithelium passes into a stratified, flat epithelium of the urethra.

\section{B. Enbryonic developinent}

In the embryo $17.9 \mathrm{~mm}$ long (the oldest stage being at my disposal, which was probably near the birth) I did not find on the Wolffian ducts any marks of gl. ampullarum buds.

\section{Juvenile stăge}

The proximal portion of the ductus deferens has an almost adult structure, but the surface cells of the canal are not ciliated yet, and a flaky secretion can be seen in the lumen. The histological structure of the distal swelling distinctly differs from the adult one. The stated differences are analogical to those described in S. araneus.

\section{Gl. prostaticae}

\section{A. Sexually mature male}

The gl. prostaticae are compound tubulo-alveolar glands surrounded by a connective-tissue sheath containing single smooth muscle fibers. There are, however, some differences in their microscopic structure if compared with gen. Sorex: The glandular elements are more compactly arrangcd, the lobular structure of the gland is considerably less pronounced, due to a relatively small amount of connective tissue and smooth muscle cells which separate single lobules (Cf. Figs. 16 and 15). The glandular epithelium is single-layered, prismatic or isoprismatic. The cells are, as a rule, regular, the round nuclei are placed in their basal portions. While in gen. Sorex the whole cytoplasm of the $g l$. prostaticae cells was filled with cosinophilous granules, in Neomys 
foliens the granules are collected only in surface portion of the cell. The secretion is eccrine. The clots of course-grained or single grains of secretion (Fig. 18) staining red with eosin and with Heidenhain's "Azan" method, are discharged from the apical pole of the cell. This kind of secretion usually fills the lumen of the alveolae. Besides the described above secretion, one also observes the alveolae filled with an almost homogenous secretion which stains red with Heidenhain's "Azan" method and pink with eosin. In this last case numerous vacuolae appear on the perimeter of the alveolae. Neither apocrine nor eccrine secretion have been observed.

The excretory tubes of both lobes of the gl. prostatica empty into the single ductus excretorius which begins half length of the gland. The ductus excretorius is lined with a very low isoprismatic epithelium and covered (being still within the gland) by a relatively thick smooth muscle coat. Both left and right excretory ducts enter the dorsal wall of the urethra, laterally to the vasa deferentia and empty into the urethra on colliculus seminalis. Their terminal part is lined with a stratified flat epithelium, the same as the epithelium of the urethra.

\section{B. Embryonic development}

Of six male embryos I had at my disposal, five have been the litter of one female, hence, in spite of the differences in sizes, they were in almost the same stage of development. Only one embryo (17.9 $\mathrm{mm}$ long) taken from another litter was much more advanced in its development, veing probably taken in the final foetal period.

Stage I (The embryos 13.3, 13.5, 14.3, 15.0, $15.2 \mathrm{~mm}$ long). Two solid epithelial buds grow (one on each side at a time) from the lateral walls of the sinus urogenitalis, in a level with the openings of the Wolffian ducts into the sinus urogenitalis (Fig. 22). The length of buds ranges from $40 \mu$ to $60 \mu$. The buds are built of "light" polygonal cells of the epithelium of the sinus, being bordered by a layer of small, dark staining cells (Fig. 24, The buds marked by an arrow) continuous with the outermost "dark" cells of the walls of the sinus urogenitalis. They lic within the differentiating $m$. urethralis.

Stage II (The embryo $17.9 \mathrm{~mm}$ long). The buds of the gl. prostaticae are undergoing farther transformations. Their size increases dorsal and cranialwards. The distal, swollen portions of the buds have grown outside the $m$. urethralis. Whereas in the former stage the circular arrangement of the mesenchyme around the buds was hardly marked, now it appears in form of a distinct glandular blastema, well-developed cranio-dorsally, and tapering posteriorly. Within the blastemas there are solid buds of 
gl. prostaticae. They are club-shaped distally, their proximal portions form narrow shafts which connect the budis with the epithelium of the lateral wall of the sinus urogenitalis. The buds are about $220 \mu$ long, being equal to the transverse axis of the canal (measured in the same level).

\section{Juvenile stage}

The structure of the gl. prostaticae in young males is similar to that in gen. Sorex. Lobular division of the gland is still distinctly seen, due to great amounts of connective tissue separating the single lobules (Fig. 20).

\section{Urethra}

\section{A. Sexually mature male}

Pars prostatica urethrae. Like in Sorex, the initial cranial portion of the epithelial canal of the urethra, is surrounded by a layer of connective tissue and by bands of smooth muscle fibers, continuous with the musculature of the gl. prostatica and of vasa deferentia. Somewhat farther caudally the smooth muscle fibers disappear, and the urethra together with the ducts is surrounded by connective tissue and striated $m$. urethralis. This muscle consisting mainly of circularly and diagonally disposed fibcrs, contains also fibers disposed longitudinally. The ducts of the gl. prostaticae (one on each side at a time) enter the dorsal wall of the urethra, laterally to the vasa deferentia, there upon, they shift towards their dorsal side, and keep this position till the outlet on colliculus seminalis (Fig. $27 \mathrm{~b}$ ). The arrangement of both pairs of those ducts on crista urethralis is similar to that of vasa deferentia and of the so-called dorsal ducts of the gl. prostaticae in S. minutus (Cf. Figs. 28 and $27 \mathrm{~b}$ ). In Neomys fodiens the ducts of the gl. prostaticae appear always in a single pair, and such is the number of their openings into the urethra. (A double lumen of the left duct seen on Fig. 27 is a lateral, temporary branching of the duct, since in farther slices it is fused with the main lumen).

In Water Shrew the structure of colliculus seminalis resembles that in gen. Sorex (Cf. Figs. 29, 26 and 30). The ducts of the gl. prostaticae empty on the apex of dorso-lateral folds, somewhat farther cranially than the vasa deferentia, whose openings are seen on the top of median fold (Fig. 29 b, a).

The structure of the epithelium of this portion of the urethra seems to be of interest, having no correspondence with either gen. Sorex, or other investigated Mammals (man included). 
The urinary bladder neck, as a rule, is lined with a stratified cuboidal (transitional) epithclium, typical for this part of the urinary tracts in Mammals, as well as for the whole pelvical part of the urethra (it may be also a stratified prismatic epithelium). The described epithelium is a typical "urethral" epithelium. In Neomys fodiens, however, almost entire pars prostatica urethrae is lined with a stratified, flat keratinizing cpithelium. The passage from the "urethral" epithelium of collum vesicae into a stratified, flat epithclium occurs in the following way: the oblong bands of stratified, flat epithelium penetrate into the urethral epithelium. Eventually, one can observe the portions of stratified, flat keratinizing epithelium and the portions of stratified prismatic epithelium arranged alternately in the same level of the urethra (Fig. 34). Farther, caudally, the canal of the urethra is built exclusively of the stratified, flat keratinizing epithelium. Big cells with light cytoplasm and granular basophilous nuclei present under characteristically stratified keratous portion, are probably leucocytes (Fig. 35).

I did not state the presence of gl. urethrales. Numerous tubules which occur in the epithelium of the cranial part of crista urethralis and in a level with urinary bladder neck (Fig. 33) have not glandular character. They should be classified as indifferent epithelial tubes, encountered rather frequently in the urinary bladder in Mammals.

Pars membranacea urethrae (pars muscularis). Within this portion of the urethra the canal courses at first cranio-caudalwards (like within the prostatic portion). Then, however, it makes an acute arc and turns ventralwards (Fig. 42 p). The epithelium lining the urethra is stratified, highly keratinous, here and there thrown into slight longitudinal folds. The connective tissue surrounding the epithelial canal of the urethra does not contain any glandular structure. The musculus urethralis is rather short, since it terminates dorsally about $650 \mu$ and ventrally, about $300 \mu$ beyond the end of colliculus seminalis. This portion of the urethra is $2 \mathrm{~mm}$ long.

Bulbus penis et sinus urethrae bulbi. The sinus urethrae bulbi occurs at the end of the arcuate bending of the canal, described above. The relatively small sinus, is directed dorso-ventrally. This can be explained by a somewhat different direction of the canal of the urethra within this portion; (cf. Figs. 42 with 39 and $41 \mathrm{~h}$ ). The depth of the sinus in its central part is merely $320 u$, its length $480 \mu$. The central portion of the sinus gives two lateral branches, (one on each side at a time) consequently, a cross-section through the whole sinus is T-shaped (Fig. 44). The gl. bulbo-urethrales ducts empty into the central portion of the sinus, close to the wall of the urethra (Fig. $42 \mathrm{k}$ ). 
The sinus lined with a stratified, flat, keratinous epithelium, is surrounded by a well-developed corpus spongiosum (Fig. $42 \mathrm{n}$ ) and covered by m. bulbo-cavernosus.

\section{Juvenile stage}

The structure of the pars prostatica urethrae is similar to that in a fully grown animal. The epithelial canal of the urethra is built of a stratified, flat epithelium, which, however, is much more keratinous, than in a sexually mature male. The lumen is filled with masses of keratinized epithelium (Fig. 37) containing a great number of leucocytes. Similar pictures are observed in the pars membranacea urethrae and within the sinus urethrae bulbi.

\section{Gl. bulbo-urethrales (s. Cowperi)}

\section{A. Sexually mature male}

Besides, the already mentioned, differences between the shape and size of those glands in Neomys fodiens and the remaining Shrews, there are also some differences in their microscopic structure. First of all, the layer of striated muscle covering the gl. bulbo-urethrales is remarkably reduced in Neomys fodiens (Cf. Figs. 46 and 45, 49 and 43). Those muscles appear only in parts, their thickness ranging from 10 to $50 \mu$. The second, striking difference, is the lack of the central cavity. Consequently, the excretory tubes join one another, and form in the central portion of the gland a system of ducts, increasing in diameter, emptying directly into the single ductus excretorius, issued from the caudomedian surface of the gland. Here, one observes the bands of connective tissue and numerous blood vessels penetrating into the substance of the gland (Fig. 49).

The excretory ducts enter the sinus urethrae bulbi (as it was already mentioned). It seems, however, possible that in the terminal portion of the ducts it may sometimes appear a lateral branching which empties into the pars membranacea urethrae, thus somewhat more cranially. Whereas in the Common and Lesser Shrews the excretory ducts are built of a single-layered epithelium (the terminal part excepted), in the Water Shrew this epithelium is stratified (2-3 layers), prismatic, and sometimes stratified, flat, keratinizing. This last appears as a rule in terminal portion of the ducts. Nevertheless, its presence has been also stated in proximal portion of the duct lying within the gland, and continuous with glandular tubes which are built of single-layered, isoprismatic epithelium. 
The ducts are almost always accompanied by smaller or greater aggiomerations of glandular tissue.

\section{B. Embryonic development}

Stage I (The embryos 13.3, 13.5, 14.3, 15.0, $15.2 \mathrm{~mm}$ long). The buds of the gl. bulbo-urethrales grow from the dorso-lateral walls of the sinus urogenitalis, at the site where the sinus passes from the pelvical part into the cavernous one, thus in the manner typical for these glands. In this stage they are already well-developed. Since the buds reach the sides of the intestine, they must have been formed somewhat earlier. Their structure is similar to that described in gen. Sorex.

Stage II (The embryo $17.9 \mathrm{~mm}$ long). Remarkable elongation of the buds and some other differences in their structure have been observed. The distal, widened portions of the buds, lying within the blastemas, extended along both sides of the intestine, show a distinct secondary gemmation. Hence, the surface of this part of the bud is distinctly tubercular. The buds are, however, lumenless both in the elongated proximal part and in the gemmating distal one.

\section{Müllerian duct (utriculus prostaticus)}

Neither in sexually mature nor in young males the remnants of the Müllerian ducts have been stated. Basing upon two embryonic stages being at my disposal, I could state that they probably disappear at the end of the foetal life (like in other Shrews).

Stage I (The embryos 13.3, 13.5, 14.3, 15.0, $15.2 \mathrm{~mm}$ long). Within the plica genitales the Müllerian ducts are non-continuous, their lumen is strongly tightened. Somewhat farther, caudally, within the funiculus genitalis, the duct is a single, solid string of cells. Only in its terminal portion the duct can be termed canaliculus, because of the distinct lumen. While joining the epithelium of the dorsal wall of the sinus (about $40 \mu$, caudalwards to the openings of the Wolffian ducts) the canaliculus becomes remarkably widened. This widened end penetrates into the epithelium of the sinus urogenitalis (Fig. $24 \mathrm{~m}$ ).

Stage II (The embryo $17.9 \mathrm{~mm}$ long). The Müllerian ducts have entirely disappeared. In the terminal portion of the funiculus genitalis, immediately before the Wolffian ducts empty into the sinus urogenitalis, one can see a band of circularly disposed mesenchyme, as the only remnant of the distal part of the Müllerian duct. 


\section{DISCUSSION}

\section{Vas deferens}

The presence of two swellings in proximal and distal portions of the vas deferens stated in gen. Sorex is rarely encountered in other Mammals. Usually one observes a single ampullary swelling occurring in the distal portion of the ductus deferens (before its entrance into the urethra). This distended part is termed an ampulla (glandulae ampullarum) and corresponds to the distal swelling in Shrews. Among the Insectivora, besides the gen. Sorex and Blarina Gray (E a di e, $1947 \mathrm{~b}$ ) similar structure of the ductus deferens has been found in gen. Hylomys $\mathrm{M} \ddot{\mathrm{u}} 1 \mathrm{l} \mathrm{e} \mathrm{r}$ and Gymnura (=Echinosorex $\mathrm{Bl}$ a in vill e) belonging to the superfamily Erinaceodica (W e b e r, 1938). Â r n bä c k C h r is t i e-L i nd e (1907), who first described those swellings in $S$. araneus, has stated that because of different structures, they are probably not homologous. (She defined the distal swelling to be a gland, as to the proximal one she gave no definition seeing only a necessity of further histological studies). None of more recent authors has investigated the histology of those structures. It was done by $\mathrm{E}$ a die $(1947 \mathrm{~b})$ who described them in S. cinereus (K e r r, 1792) and Blarina brevicauda (S a y, 1823). He has stated that the distal swelling constitutes the true glandulae ampullarum, while the proximal swelling is only a spermatic storehouse. (He did not give, however, any detailed histological analysis). Nevertheless, in another paper, the same author ( $\mathrm{E} \mathrm{a} \mathrm{d} \mathrm{i} \mathrm{e,} \mathrm{1951)} \mathrm{has} \mathrm{included}$ the proximal swelling to the accessory glands. (He has made a list of accessory glands in Insectivora, mentionning that two pairs of $g l$. ampullarum occur in gen. Sorex and Blarina).

Considering the present investigations it seems that the proximal swelling of the ductus deferens occurring in gen. Sorex cannot be identified with the gl. ampullarum. It has been shown that the glandular function of the epithelium lining the lumen and sinuses of this swelling is not greater than that stated in the epithelium of the deferent duct immediately after leaving the epididymis. The secretion ability of the epithelial cells of the ductus deferens is well known, and has been stated in almost all Mammals (B e n o it, 1926). The epithelium of the proximal swelling and that of the vas deferens have almost the same structure (a pseudostratified, cilliated epithelium). Since the proximal swelling is always filled with sperm, it probably serves as storehouse for the spermatozoa, in addition to the epididymis.

The distal swelling (the ampulla of the ductus deferens) being in gen. Sorex and Neomys completely homologous, constitutes the true $\mathrm{gl}$. 
ampullarum. In the three investigated species of Shrews the distal swelling begins more or less in the middle of the vas deferens (in Neomys fodiens somewhat nearer) and continues up to the entrance of the ducts into the crista urethralis. According to E a d i e (1947 b) in Blarina this gland is terminated before the entrance of the duct into the dorsal wall of the urethra, thus analogically to Crocidura Wagle r ( $\dddot{\mathrm{Arnbä}} \mathrm{ck}$ Christie-Linde, 1907; G odet, 1951). It is obvious that the distal swelling occurring in gen. Sorex, Neomys and Blarina is homologous with that in Crocidura (although there are no data concerning its histological structure). Thus in all investigated Shrews there is only one pair of completely homologous gl. ampullarum. Their main function is to produce the secretion, the number of spermatozoa seen within the glands being too small to assign them any important part in collection of the scmen.

The formation of gl. ampullarum during the embryonic development takes place remarkable later than the formation of other accessory glands. In embryos whose $g l$. prostaticae and gl.bulbo-urethrales buds have been well-developed (e. g. the $17.9 \mathrm{~mm}$ embryo of Neomys fodiens) the Wolffian ducts are still uniformly developed through-out their whole length. This is consistent with the data given by Eadie (1947) b) for $S$. cinereus and $B$. brevicauda. Szarski (1935) who investigated the development of those glands in the White Mouse, has stated that the first buds appear not earlier than in newly born animals. Since the $g l$. ampullarum in Shrews are lying within the walls of the ductus deferens, there is no doubt as to their origin.

The structure of the gl. ampullarum in Shrews is not exceptional among the Mammals. Similar structure of those glands has been described by Disselhorst (1904) in Oryctolagus cuniculus Linna e us, 1758, and Equus caballus L innaeus, 1758; by Grosz (1905) in Cricetus frumentarius ( $\mathrm{Pallas}, 1811$ ). In the White Mouse, however, (R i tschel, 1929; Szarski, 1935) and in Microtus arvalis (P a $1 \mathrm{las}, 1779$ ) $\mathrm{Delost}$ (1955) the structure of the ampulla of the ductus deferens is somewhat different (a wide, irregular central lumen epithelial slats built of glandular cells bulging inwards). In the last two species, as well as in Cricetus, there are also some free glandular tubes grown beyond the wall of the vas deferens. R a uther (1904) and Grosz (1905) in gen. Sciurus Linnaeus, 1758 have stated only free glandular tubes and a complete lack of glands embedded in the walls of the ductus deferens. which therefore does not form any swelling (ampulla). According to $\mathrm{Szarski}$ (1935), the al. ampullarum, entirely embedded in the walls of the ductus deferens, are a most primitive form of those glands, free 
ampullar tubes and vesiculae seminales present in numerous Mammals being a further stage of their differentiation. The occurrence of only first type of those glans in Shrews and a complete lack of gl. ampullarum in some Insectivora, considered to be the most primitive (e. g. Tenrecoiden - K a u d e r n, 1911), seem to support the above hypothesis.

\section{Gl. prostaticae}

There are different opinions as to the structure of the gl. prostaticae in Mammals. Some authors describe them as compound tubular glands, while the others assign to them a tubulo-alveolar structure. Grosz (1905) describes the gl. prostaticae in Talpa europaea L in n e us, 1758 as compound tubular glands, while E ad i e $(1947 \mathrm{~b}$; 1948) states that in Talpidae those glands have a tubulo-alveolar structure. An explanation of this complicated problem can be found in $\mathrm{Schm}$ al t z (1911, quoted aiter $\mathrm{G}$ e $\mathrm{r}$ a r d t, 1938). On the ground of histological analysis of the accessory glands in domestic animals, the above author has come to a conclusion that the origin of all accessory glands may be traced from tubular glands. In single cases, however, the tubular character of glands may be blurred by the occurrence of distended terminal portions of the tuibes filled with secretion, much resembling the alveolae. For this reason such glands are often described as tubulo-alveolar glands. From my own observations it follows that in young Shrews the gl. prostaticae have an appearance of branched tubes, but in fully grown animals the terminal branches assume an alveolar appearance. For this reason I have defined them as compound tubulo-alveolar glands.

From the above given examples it clearly follows that the applied methods yield a rather subjective definition of the structure of glands. Therefore, in this kind of investigations the photographs should be rather used, making possible an objective comparison of those glands in different Mammals. Unfortunately, the photographs are rarely encountered in papers.

So far, the histological structure of the accessory glands in Insectivora has no.t been sufficiently known. Therefore their detailed analysis within this order is rather difficult. There are, however, more available data concerning the development of the gl. prostaticae in the representatives of three families belonging to Insectivora: Talpidae, Soricidae (including tnis paper) and Erinaceidae. The available data allow to state the homology of $\mathrm{gl}$. prostaticae in the mentioned above Mammals.

To begin with Talpidae, Godet (1949) has stated that in Talpa europaea the gl. prostaticae develop from 2 pairs of buds formed from the ventral and ventro-lateral walls of the sinus urogenitalis. In 
Parascalops True (E a d i e, 1947 a) they develop from a single pair of ventro-lateral buds. In Galemys pyrenaicus G e of $\mathrm{f} \mathrm{roy,} 1811$ (according to P e y r e, 1959) those glands develop, like in Talpa, from two pairs of buds, derived from the ventral and lateral walls of the sinus. E a d i e (1947) b) who has investigated the Soricidae, stated that in $S$. cinereus and in $B$. brevicauda the prostatic glands develop from a single pair of buds, formed from the ventro-lateral walls of the sinus urogenitalis. In $S$. araneus and $N$. fodiens I have stated a single pair of buds formed from the lateral walls of the sinus urogenitalis. In $S$. minutus Lin$\mathrm{n}$ a e u s, 1766, however, in addition to the lateral buds, there occur also some the ventro-lateral buds, varying in number.

Thus, in all species, the gl. prostaticae are always developed from the lateral or ventral walls of the sinus urogenitalis. If we consider other cryterions, like structure and position, we come to a conclusion that the gl. prostaticae in the mentioned above Mammals, are homologous.

It must be emphasized that the prostatic glands in all investigated fully grown males of the mentioned above species are always single-paired. Nevertheless, the number of buds during the embryonic development may be greater (E. g. 2 pairs in Talpidae or even more in Lesser Shrew). It seems that the the number of buds does not correspond to the number of glandular lobes occurring in a fully grown male, but to the number of the excretory ducts of these glands. This hypothesis has been suggested by a variable number of the excretory ducts of the $g l$. prostaticae observed in $S$. minutus, and the variable number of the buds of these glands, occurring during the development in this species.

In $S$. araneus and $N$. fodiens the gl. prostaticae develop from a single pair of epithelial buds, growing from the lateral walls of the sinus. Consequently, grown up males have always one pair of excretory ducts, opening on the dorsal wall of the sinus urogenitalis, laterally to the ductus deferens. This displacement becomes quite comprehensible if we consider the fact, that during the process of development both lateral and dorsal walls of the sinus urogenitalis increase their sizes very intensly ( $\mathrm{S}$ z a r k i, 1935). This undoubtly brings about the displacement of ducts from a lateral position to the dorsal one. In $S$. minutus the way of formation and the localization of the openings of the dorsal ducts of gl. prostaticae in fully grown individuals, prove their homology with excretory ducts of $g l$. prostaticae in $S$. araneus and $N$. fodiens. During the embryonic development of this species one observes a variable number of the ventro-lateral buds which this being in line with the variable number of the dorso-lateral and lateral ducts of gl. prostaticae in a fully grown male. It seems that more detailed investigations conducted on 
a larger material would lead to conclusion that a variable number of gl. prostaticae ducts in fully grown males, related with a variable number of buds of these glands in embryos is a phenomenon fairly frequent among Mammals. This hypothesis has been based on the following data found in the literature: O udemans (1892) and D iss el h or s t (1904) have stated, that in Talpa europaea the gl. prostaticae empty into the urethra by means of a single pair of ducts. Grosz (1905) has found in the same species two pairs of ducts, and $\mathrm{K}$ a u de $\mathrm{r}$ (1911) has stated the presence of two pairs of ducts in four male specimens, and two ducts on one side and three on another one in one individual (the total number of investigated males being five). G r o s z (1905) has stated that in Oryctolagus cuniculus the gl. prostaticae have as a rule four excretory ducts on each side, nevertheless, he found in one individual five ducts on the left-hand side and four ducts on the right one. In Neomys fodiens Ka ude r n (1911) has described two pairs of ducts, while according to the present investigations, this species has only one pair of the gl. prostaticae ducts. Finally, R a yna ud (1951) has mentioned a variable number of prostatic glands ducts in Microtus agrestis ( $\mathrm{L}$ innaeus, 1761). Although $\mathrm{R}$ a y na ud has not studied their development, he supposes that the number of buds ought to be the same as the number of their openings.

In view of the mentioned above facts, the statements, like that given below, (K a u d e r n, 1911): „So steht Crossopus (=Neomys) den Talpiden dadurch nahe, dass die Prostata auf jeden Seite mit 2 Ausführungsgängen mündet" - seem to be wrong.

Finally, some words devoted to the phylogenetic development of the yl. prostaticae in Mammals.

Following the hypothesis of $\mathrm{Oudemans}$ (1892) that the glandulae prostaticae are a group of gl. urethrales distinguished phylogenetically, the presence of a uniform ring of glandular tubes surrounding the pars prostatica urethrae (e. g. in Bats) is the most primitive stage in phylogenesis. Consequently, the differentiation of the gland into three distinct groups: ventral, lateral and dorsal (each of them emptying into the urethra by means of many excretory ducts) observed in many Mammals (Rodentia) is the next step in the development. According to this hypothesis, in such a primitive order, like Insectivora, at least three groups of gland, unless the ring of glandular tubes should be expected. Neither of these supposition is, however fulfilled. Insectivora, as a ruie, have one pair of very well distinguished prostatic glands, emptying into the urethra with one or two pairs of excretory ducts. The buds of those glands being developed from the lateral or ventral walls of the sinus 
urogenitalis (see above) are homologous to the lateral or ventral groups of prostatic glands in Rodentia. Their homology may be, moreover, confirmed by a similar structure of gl. prostaticae in Shrews and of ventral and lateral groups of prostate in Rodentia. This resemblance has been stated by comparing histological pictures of $g l$. prostaticae in the investigated Shrews and in Microtus arvalis. Both in Shrews and in Microtus arvalis the lateral and ventral tubes of the gl. prostaticae are built of a prismatic epithelium with granular cytoplasm and basally disposed nuclei.

\section{Urethra}

The data concerning the anatomical structure (histological in particular) of the urethra in different Mammals are very scarce in the literature. Most data concern the structure of the colliculus seminalis and the openings of the gl. accessiorae. Of the Insectivora only the classical objects, like the Mole and the Hedgehog have been elaborated in details.

A large, blind diverticulum of the pars prostatica urethrae in the Mole and the Hedgehog, continuous cranially with the urogenital canal, has been described by different authors as sinus genitalis or vagina masculina (O u d e mans, 1892; R a u the r, 1904; G rosz, 1905 and etc.). Momba e r ts (1944) who studied the development of the sinus urogenitalis in the female and male of the Hedgehog has stated that this diverticulum being homologous with the vagina in the female deserves the term vagina masculina. G od et $(1949,1950,1951)$ studying the development of the sinus urogenitalis in the Mole and for the second time in the Hedgehog, has stated that the diverticulum results from the overgrowth of the dorsal wall of the sinus urogenitalis, and being developed in a manner entirely different from the female vagina, is eo ipso a typical male structure. He has termed this diverticulum ,une poche prostatique". In the Hedgehog the overgrowth of the dorsal wall of the canal is so intense, that it brings about the displacement of many ducts: the vasa deferentia, the gl. prostaticae ducts and even the gl. bulbo-urethralss ducts, which in a fully grown male empty within this diverticulum. In the Mole, the diverticulum being not so well developed, the vasa deferentia enter the urethra at the point where the diverticulum begins, and the gl. prostaticae ducts empty somewhat below, entirely beyond the diverticulum. The presence of a similar pocket-like sinus in the pars prostatica urethrae in a representative of the family Soricidae, Crocidura russula, (H e rmann, 1780) has been described by Godet $(1950,1951)$. In all, mentioned above, animals the pars prostatica urethrae 
is remarkably distended. This part called by $\mathrm{M}$ o $\mathrm{mbaer} \mathrm{s}$ the bulbus urethralis has, according to this author, nothing in common with the bulbus urethralis occurring in man. Godet has termed it the bulbus prostaticus.

In the investigated Shrews no structures of this kind have been found. Exteriorly the pars prostatica urethrae in these animals is almost uniformly swollen, and there is no diverticulum within the colliculus seminalis.

In all investigated Shrews the colliculus seminalis has a similar structure (despite a variable number of the gl. prostaticae ducts in S. minutus). The vasa deferentia always empty on the top of the dorsal, median fold, the prostate ducts open laterally to them, either on the top of lateral dorsal folds or into the dorsal grooves, bordering the median

The colliculus seminalis in Shrews is relatively feasbly distinguished, (1947 b) in B. brevicauda and S. cinereus.

The colliculus seminalis in Shrews is relatively feebly distinguished, as compared with other Mammals. It does not form a single, distinct point projecting inward the lumen of urethra, like e. g. in Muridae.

There are no essential differences in the histological structure of the urethra between both species of gen. Sorex and other Mammals.

The presence of a stratified, flat, keratinizing epithelium in the urethra of $N$. fodiens seems, however, to be quite exceptional phenomenon in Miammals. This kind of epithelium is usually found in terminal parts of pars spongiosa urethrae, and (as far as I know) never in pars pelvina urethrae. Such an epithelium occurs in $N$. fodiens as early as in sexually immature males (Fig. 37), the process of keratinization being there more advanced than in fully grown animals. In the remaining Shrews and in the males of $M$. arvalis the epithelium lining the urethra is stratified prismatic or cuboidal.

The described above structure of the epithelium in $N$. fodiens as well as the presence of leucocytes resemble the epithelium lining the vagina and the pars vaginalis uteri in Mammals during dioestrus and metoestrus stages, because of keratinization of epithelium and infiltration with leucocytes. This phenomenon is not easily explained. A different origin of the epithelium of the urethra in $N$. fodiens does not seem to be possible. It may be shown (e.g. the vagina) that such a type of epithelium (stratified, flat) like other kinds of epithelium, is not related with any determined germ-layer (in this case with ectoderm), since the vagina may be of a miscelaneous origin (ecto-meso-entodermal) (F o r s b e r g, 1963), but, as a rule, is lined with a stratified, flat, keratinizing cojthelium. It is possible that this phenomenon is due to some factors 
different from other Mammals which may be related with the aquatic way of life of Neomys fodiens.

The next interesting problem is the lack of whichever kind of $g l$. urethrales in the urethra of Shrews. My observations are in line with investigations of $\mathrm{E}$ ad i e $(1947, \mathrm{~b})$ on $S$. cinereus and $B$. brevicauda, but contradict the data given by $\mathrm{Kauder} \mathrm{n}$ (1911) who has found and described such glands in Common and Water Shrews. This contradictions scems to result from a wrong interpretation given by $\mathrm{K}$ a u der $\mathrm{n}$. He has probably considered the indifferent epithelial tubes present in the wall of the urethra of the investigated Shrews, to be true gl. urethrales. These glands have not been found in the Mole either. Only in the Hedgehog there is a pair of glands which because of their position within the $m$. urethralis and because of their structure have been considered to be the gl. urethrales ( $\mathrm{G}$ o d e t, 1952).

This sporadic occurrence or a complete absence of gl. urethrales in Insectivora is rather unexpected a phenomenon. According to generally assumed opinion, the gl. urethrales are the most primitive accessory glands of the urethra, which had differentiated in the process of phylogenesis into two large groups of glands: cranially they gave rise to the gl. prostaticae, and caudally, to the gl. bulbo-urethrales. This hypothesis, put by Oudemans (1892), was subsequently supported by such authors, like: R a u ther (1904), Grosz (1905) and Szarski (1935). it may be confirmed by many facts: In Monotremata the gl. urethrales are exceptionally well-developed (The gl. prostaticae are not present yet, there are, however, the gl. bulbo-urethrales). The same situation has been stated in Marsupialia, where the gl. urethrales were described as $\mathrm{gl}$. prostaticae. The gl. urethrales are commonly observed in Ciiiroptera. Among Rodentia thcy are very well developed in Muridae. Thus, the gl. urethrales occur in all groups of Mammals which are considered to be the most primitive. There is, moreover, a striking convergence in the microscopic structure of those glands and of gl. bulbo-urethrales (see the next chapter). On the other hand, as it has been shown by more recent experiments ( $\mathrm{R}$ a y n a $\mathrm{ud}$, 1949; G od et, 1952), the $g l$. urethrales, unlike the $g l$. prostaticae and gl. bulbo-urethrales, do not atrophy after the castration nor overgrow after being treated with hormones. Thus they are rather loosly related with reproductive functions. From the investigations on the origin of the epithelium of sinus urogenitalis in some Mammals it follows, moreover, (see Terminology, p. 73) that the cavernous portion of the urethra may derive from the ectoderm, unlike the pars pelvina. This fact would, consequently prove a different origin of gl. bulbo-urethrales (cctodermal) and 
a miscelaneous origin of $g l$. urethrales these last being also encounterci in Rodentia within sinus urethrae bulbi. The mentioned above facts, as well as the absense of gl. urethrales in the investigated species of Insectivora (an undoubtly primitive order) give counterevidences to the hypothesis of O u d e mans.

There exists in the structure of the canalis urogenitalis in Mammals a rather interesting feature, which, however, is usually treated marginally by other authors. I mean the sinus found within the bulbus penis on the boundary of pars membranacea and pars spongiosa urethrae. Considering the data found in the literature, it may be inferred that the sinus occurs in Mammals rather frequently, and that the ducts of gl. bulbo-urethrales are, as a rule, emptying into it. As early as in $1892 \mathrm{O} u \mathrm{~d}$ e $\mathrm{m}$ a $\mathrm{n} \mathrm{s}$ described such a sinus in Sus and Ruminantia and in some Marsupialia. R a u the r (1909) has stated its presence in Orycteropus, Otomys and Myrmecophaga. Grosz (1905) has described it in Dipus aegyptius $\mathrm{H}$ a s selg., $\mathrm{K}$ a uder $\mathrm{n}$ (1911) in numerous Insectivora, Mossman (1932) in Tamiasciurus hudsonicus (Erxleben, 1777), Szarski (1935) in Mus musculus Linnacus, 1753, and $\mathrm{R}$ aynaud (1951) in Microtus agrestis. Of the above mentioned authors only $\mathrm{Ka} \mathrm{udern} \mathrm{(1911)} \mathrm{and}$ $\mathrm{Szarski}$ (1935) have paid more attention to its possible role. It seems, however, that more detail investigations would lead to the conclusion that the occurrence of this sinus is widespread unless common in Mammals. Even in man one can find an analogy between the swelling of the initial portion of the pars spongiosa urethrae (ampulla urethrae), the outlet of the gl. bulbo-urethrales ducts and the sinus urethrae bulbi.

The very existence of such a sinus in various Mammals can be deduced from the descriptions given by different authors. The data concerning its shape or structure are, however, very scarce. Some sketches of this region of the urethra, often very schematic, can be found quite exceptionally (O udemans, 1892; R a y n a d, 1951). The detailed pictures of this portion of the canalis urogenitalis have been given only by $\mathrm{Ka}$ a der $\mathrm{n}$ (1911). This author gave the description of the sinus in different species belonging to Insectivora ${ }^{3}$ ). A well developed sinus occurs in species belonging to Tenrecoidea and Macroscelidoidea. In Chrysochloroidea its development is much weaker (only one species has been described), and in Erinaceoidea does not exist at all. As to the Soricoidea, it appears in Soricidae and is absent in Talpidae. (This last statement, however, does not seem to be quite reliable, although neither Godet nor E ad i e mention the existence of the sinus in Talpidae. My objections have been suggested by the photograph of a cross-section

3) Based on the classification given by $\mathrm{S}$ i m p s on (1945) 
through the urethra, given by E a d i e (1947 a, Pl. 2, Fig. 8). The ducts of these glands empty, like in $N$. fodiens, into an elongated sinus, continuous dorsally with the lumen of the urethra. Finally, in Tupaja javanica $\mathrm{K}$ a u d e r n (l. c.) has stated the presence of very poorly developed sinus urethralis.

It seems that the sinus can be easily overlooked because of its small dimensions or when the available material is too scarce. E. g. K a u d e r n (1911) did not find it in $N$. fodiens (he had only one individual at his disposal), while the present investigations have shown its existence in this species (Fig. 42), it is, however, much smaller than in gen. Sorex.

Both frequency and size of the sinus urethrae bulbi in Mammals seem to be of interest. So far, everything suggests that it is best developed in Insectivora. where it occurs in form of a true pocket, blind-ended cranially (e. g. Tenrec, Potamogale, Macroscelides - Ka u d e r n, 1911, and, following my experiments, Sorex).

So far, no conclusions can be drawn yet. Nevertheless, let us quote Ka u dern (1911): "Wenn die Ansicht von Boas richtig, ist, dass die placentalen Säugeticre während der Entwicklung ein Nonotremenstadium durchlaufen, dann würde der betreffende Blindsac möglicherweise ein ungebildeter Rest des Urogenitalkanals sein können, der bei den Monotremen in direkter Verbindung mit dem Darm steht". Thus, considering this point of view, the presence of the sinus would be a very old phylogenetic character.

\section{Glendulae bulbo-urethrales}

In almost all Mammals, with except of aquatic ones, as Pinniperia, Cetacea, Sirenia and some Carnivora (O u demans, 1892, D is selhorst, 1904), the glandulae bulbo-urethrales are usually single-paired.

Of all accessory glands the gl. bulbo-urethrales are best defined. The glands lie dorsally close to the bulbus penis, they have one pair of excretory ducts emptying on the boundary of pars pelvina and pars spongiosa urethrae, finally, they are covered by coat of striated fibers muscle. There is also a striking resemblance in the internal structure of these glands in Mammals. Some differences given in the description of various authors results from the employed criteria, which appeared to be much subjective (like in the case of the gl. prostaticae). O u d e m a n s (1892), D is s e l h or s t (1904) and G r o s z (1905) describe them as either compound alveolar or tubulo-alveolar glands, whereas most authors assign in them a tubular structure. All authors, however, are unanimous while describing the glandular epithelium. They define it as cylindrical one with basally disposed nuclei. The glandular elements are tightly arran- 
ged, the amount of connective tissue within the gland being scarce. The pictures enclosed to their papers are usually schematic, and the lack of photographs does not allow to make any accurate comparison.

In the description of the gl. bulbo-urethrales I have defined them as commpound tubulo-alveolar glands. Both in longitudinal and cross-sections the main glandular elements have the appearance of more or less regular alveolae with a tightened lumen and a high prismatic epithelium. These elements differ from the elements characterized by a distinct lumen, lined with an isoprismatic epithelium, and by a distinctly tubular structures. The last tubes empty either into the central cavity, or (as in Neomys fodiens) fuse into the ducts with an increasing diameter and empty into the ductus excretorius.

The presence of central cavity within the gland does not seem to be a constant character. It has been stated in the following genera belonging to Insectivora: Talpa (G r os z, 1905), Myogale (K a u der n, 1911), Condylura (E a d i e, 1948), Sorex (my investigations, and E a d i e, $1947 \mathrm{~b}$ in $S$. cinereus), while in Erinaceus (Mombae $\mathrm{rts}$, 1944), Blarina (E a di e, 1947 b), Parascalops (E a d i e, 1947 a) and Necmys (my investigations) the central cavity being absent is replaced by a system of very strongly branched tubes.

The excretory ducts of the gl. bulbo-urethrales are usually very long and lined with a single-layered, prismatic epithelium (e. g. in Common and Lesser Shrews), which sometimes can be stratified. $\mathrm{Rauth}$ cr (1904) has found a double-layered epithelium in Oryctolagus cuniculus. Grosz (1905) has described it in the Hedgehog. Thus the presence of a stratified epithelium (2-3 layers) in the ducts of the gl. bulbo-urethrales in $N$. fodiens is nothing unusual, but the local keratinization of this epithelium being not mentioned in the literature seems to be quite special a phenomenon.

The occurrence of glandular elements associated with the gl. bulbo-urethrales ducts is commonly known. In Shrews these glands are disposed throughout the almost entire length of the ducts. Le y dig (1850) has described such a duct with the associated glands in the Mouse. His findings have been subsequently confirmed by $R$ a $u t h$ e $r$ (1904) in the Mouse and the Rabbit. Grosz (1905) has stated the presence of thosc glands in Dipus aegyptius. M os sma n (1932) has decribed the glands associated with ducts in Sciuridae, mentioning that such glands can be also encountered in the Guinea pig and Man. E a di e (1948) has given the description of the gl. bulbo-urethrales ducts in Condylura. They have the same glandular wall as the true gland, the epithelium changes into a stratified one not earlier than immediately before entering the urethra 
This last observation has been fully confirmed in Shrews.

$\mathrm{R}$ a u ther (1904) and Szarski (1935) have drawn their attention to the fact that in Mouse the glandular elements associated with the ducts of gl. bulbo-urethrales are identical with the gl. urethrales, which in this species occur in great quantities throughout the length of the urethra. For $\mathrm{R}$ a $\mathrm{uth}$ er this phenomenon proves the hypothesis of Oudemans as to the origin of gl. bulbo-urethrales from the $g l$. urethrales.

In Shrews the gl. urethrales do not occur. Nevertheless I could sec them in urethra of Microtus arvalis. I have stated that their structure is almost identical with glandular elements associated with ducts and with the elements of the very glandulae bulbo-urethrales in Shrews. This proves, among others, an unusual stability of those structures in Mammals.

In all investigated Shrews the buds of gl. bulbo-urethrales are always single-paired. They develop from the dorso-lateral walls of the canalis urogenitalis, in point, where this last passes from the pars pelvina into pars cavernosa. The same way of formation of the buds of gl. bulbo-urethrales has been described by E adie $(1947 \mathrm{~b})$ in $S$. cinereus and B. brevicauda, and by G od e t (1949), E a d i e (1947 a) and P e y r e (1959) in Talpidae. They develop in the same manner in other Mammals: in Man (M ü lle r, 1892), Mouse (S zar ski, 1935; R a y n a u d, 1942).

All authors agree that of all gl. accessoriae the gl. bulbo-kirethrales are first devoloped. This fact has been stated in all investigated Shrews. In Common and Water Shrews the buds of gl. bulbo-urethrales are well-developed before the buds of gl. prostaticae appear. (The distal ends of gl. bulbo-urethrales buds reach as rule the sides of the intestine). In a $8 \mathrm{~mm}$ long embryo of Lesser Shrew the buds of $g l$. prostaticae are not present yet, but the gl. bulbo-urethrales buds are already developed.

$\mathrm{Szarski}$ (1935) who investigated the develcpment of the gl. bulbourethrales in the White Mouse has drawn his attention to the fact that "during the development of other accessory glands, the growing bud moulds the surrounding tissue by either pushing it forwards ( $g l$. prostaticae II, III) or growing into the already existing stroma which surrounds other organs (e. g. gl. prostaticae I, vesiculae seminales); while the gl. bulbo-urethrales develop in entirely different way. In early stages one can distinctly see a pair of blastemas which grow independently from the bulbus penis assuming the shape of the future gl. Cowperi, while the true epithelial buds are hardly reaching their bases". This observation has been partially confirmed by my own investigations. In a $11.6 \mathrm{~mm}$ long embryo of $S$. araneus the epithelial buds of gl. bulbo-urethrales are not yet reaching their blastemas, those last being already formed, lie on 
both sides of the intestine. I could not state, however, whether these blastemas had derived from the blastema of bulbus penis. It seems, that the observations made by Szarski (1935) are in line with our present knowledge concerning the development and structure of the glands in question in Mammals. In a fully grown animal the gland is covered by a layer of striated muscle which cannot be formed from the mesenchymatic tissue (as it takes place in the case of smooth muscle of gl. prostaticae or vesiculae seminales). Therefore, the relation between the blastema of the gl. bulbo-urethrales buds and the blastema of the bulbus penis seems to be quite probable. Consequently, the origin of $g l$. bulbo-urethrales muscular layer from $m$. bulbo-cavernosus is also much probable.

The above given data concerning the development, and structure of the gl. bulbo-urethrales and their excretory ducts are sufficient enough to state homology of those glands with the gl. bulbo-urethrales in other Mammals. The same statement refers also to $N$. fodiens (In $N$. fodiens the proper place of those glands in the classification of accessory glands has been so far disputed).

The homology of gl. bulbo-urethrales in Neomys fodiens with the $g l$. bulbo-urethrales in other Mammals has been put in question by Ka udern (1911). This author has stated that in $N$. fodiens the $g l$. bulbo-urethrales are lacking the striated nuuscle layer, and that the openings of their ducts lie "somewhat higher" than in Sorex and Crocidura. My own investigations have shown the existence of certain differences in the structure of those glands, compared with Common and Lesser Shrews: The gl. bulbo-urethrales in Water Shrews are smaller and spherical in shape, the coat of striated muscle is much reduced (for this reason being probably overlooked by $\mathrm{K}$ a u de $\mathrm{r}$ ), finally, they are lacking the central cavity (Figs. 46 and 49). Since in typical aquatic animals the gl. bulbo-urethrales are absent, the reduction of muscular coat and relatively smaller dimensions of those glands in Water Shrew can be considered as regressive characters. The lack of central cavity being frequently observed in this type of glands, does not seem to be any essential character either. The last argument used by $\mathrm{K}$ a u der $\mathrm{n}$, namely, that the openings of the excretory ducts are situated nore cranially than in cther Shrews, can be also confuted. The excretory ducts of the gl. bulbo-urethrales empty as a rule into the sinus urethrae bulbi. Jt may happen, however, that the terminal portion of this duct gives a secondary branch which opens into the pars membranacea urethrae, thus more cranially than usual. 


\section{Müllerian duct (utriculus prostaticus)}

Although the investigated embryos of Shrews represented a small number of separate stages, the regression of Müllerian ducts in Shrews has appeared to be similar to the regression of this organ in other Mammals ( $\mathrm{K}$ w i e t $\mathrm{n}$ i e w s k i, 1910); $\mathrm{R}$ a y $\mathrm{n}$ a $\mathrm{u} \mathrm{d}, 1942$; $\mathrm{G}$ o d e t, 1949; Delost, 1951). The cranial portions enclosed within the plica genitales aegenerate first. In distal portion lying within the funiculus genitalis both ducts fuse into a single duct, which gradually atrophies. In the oldest embryos of $S$. minutus $(13 \mathrm{~mm}$ long) and S. araneus $(14.5 \mathrm{~mm}$ long) only the distal, terminal portion of the ducts remains in form of a canaliculus joining the dorsal wall of the sinus between the Wolffian ducts, i. e. in a level with their openings into the sinus urogenitalis (Figs. 54, 55). This structure deserves to be termed the utriculus prostaticus. In the $17.9 \mathrm{~mm}$ long embryo of Neomys fodiens this terminal portion is also almost entirely atrophied. Hence, the utriculus prostaticus in Shrews is present only in embryonic stages and disappears before the birth. Neither in young nor in sexually mature males any remnants of those structures have been ever found.

In some related species: $S$. cinereus and $B$. brevicauda the utriculus prostaticus occurs only in embryos (E a d i e, $1947 \mathrm{~b}$ ). Analogical situation has been stated in the Hedgehog ( $\mathrm{M} \mathrm{o} \mathrm{m} \mathrm{b} \mathrm{a} \mathrm{e} \mathrm{ts}, 1944)$ and in Parascalops (E a die, 1947a). Among Insectivora only in Galemys pyrenaicus (P e y r e, 1959) the distal remnants of those ducts may remain in sexually immature malcs.

\section{General remarks}

G o d e t expresses his opinion concering the development of the male reproductive system within three families (Erinaceidae, Soricidae and T'alpidae) of Insectivora in a series of papers (G o d e t, 1950, 1951, 1952). He comes to a conclusion that the Talpidae are the most primitive, the Soricidae are intermediate and the Erinaceidae are the best developed. Since he has investigated only one species belonging to Soricidae [Crocidura russula ( $\mathrm{H}$ e r m a $\mathrm{n}, 1780$ )] his conclusions referring to the structure of the genital system within this family may be sometimes doubtful.

Godet has based his evolutionary conception on: (1) the structure of vas deferens and (2) the structure of pars prostatica urethrae. As to the first item the way of his reasoning runs as follows:

Considering his own investigations (Godet, 1949, 1951) and the results of Eadie $(1947 \mathrm{a}, 1947 \mathrm{~b}, 1948,1951)$ Godet states the $g l$. 
ampullarum in Talpidae lie at the beginning of vas deferens adjoining the epididymis, in Crocidura russula (a representative of Soricidae) they lie in the half length of the deferent duct, being absent in Erinaceus europaeus Linnaeus, 1758. In the last family, there are instead the vesicula seminales which in the process of development are formed from the distal portion of the ductus deferens, thus they can be considered as "independent" gl. ampullarum. This hypothesis was given first by $\mathrm{Sz}$ a rski 1935. For G o d e $t$ this is a distinct evolutionary sequence.

On the ground of the description of an ampulla or "reservoir spermatique" (the most often used term which defines this structure in the Mole: O u d e man s, 1892; R a u th e r, 1904; Grosz, 1905 and others) it seems that the ampulla is not a true gl. ampullarum. It is a structure corresponding rather to the proximal swelling of the ductus deferens in Shrews, whose main fuction is to be a storehouse for spermatozoa. My suppostition has been confirmed by a photograph of this structure in Condylura (E a d i e, 1948, Fig. 4), and by the statement given in another paper (E a die, 1951, Table I) that all investigated species of Talpidae are lacking gl. ampullarum.

Concequently, the gl. ampullarum denoted by $\mathrm{Godet}(1952)$ by $\mathrm{A}_{3}$ (p. 29, Fig. 1; see also Terminology) probably do not occur in Insectivora.

This statement does not contradict the validity of the general hypothesis on the development of the above glands, assumed by this author. It is quite possible that in Shrews the true gl. ampullarum present in the distal portions of the ductus deferens had been formed in the course of evolutionary development from such pocket-like structures, as "reservoire spermatique" in Talpidae or the proximal swelling of vas deferens in Shrews.

While the first premise of the evolutionary hypothesis given by G o$\mathrm{d}$ e $\mathrm{t}$ is quite acceptable, the second one (considered by this author as fundamental) seems to be groundless and false. The above refers to the structure of the pars prostatica urethrae in the representatives of the three investigated species of Insectivora.

According to G o d e t $(1950,1951)$ the presence of a so-called prostatic diverticulum is a character marking the progression. Having stated the best development of this diverticulum in the Hedgehog, and the worse one in the Mole, God e $t$ sees in this fact a distinct line of development: Talpidae - Sorcidae - Erinaceidae.

Since the presence of the above diverticulum has not been stated in any of the investigated Shrews, and considering the objections as to the description of this diverticulum (God e t, 1951) its presence in Crocidura russula seems to be highly doubtful. If, moreover, we take under 
consideration the picture of this region of the urethra in Crocidura russula, given by $\mathrm{G}$ ode $\mathrm{t}$ in the same paper ( $\mathrm{Godet} l$. c. Fig. 7) it will become quite evident that structure described by $G$ od e $t$ as bulbus prostaticus is the bulbus penis, and that the diverticulum found within the bulbus is the sinus urethrae bulbi. This hypothesis may be confirmed by the fact, that $\mathrm{Kauder} \mathrm{n}$ (1911) who has described the anatomical structure of the male genital system in Crocidura indica $\mathrm{R}$ obinson $\& \mathrm{Kloss}, 1922$, does not mention the existence of sinus genitalis (prostatic diverticulum). On the enclosed sketch (K a u d e r n, l.c., p. 50, Fig. Oa) he clearly distinguishes the bulbus penis, the sinus urethrae bulbi and the gl. bulbo-urethrales emptying in to the sinus.

If we even neglect the fact that in light of the present investigations and, the mentioned above objections, the existence of a prostatic diverticulum in Soricidae is much doubtful, there are general objections as to its value as the cryterion of the evolutionary development.

Considering the available data it seems that the diverticulum occurs only in two representatives of Talpidae, namely in Talpa europaea and, thougn in a much reduced form, in Scalops aquaticus (L innaeus, 1758), (K a u der n, 1911)). It is also well-known that the occurrence of such unpaired or paired blind diverticula in pars prostatica urethrae being rather common in Mammals, does not show any regularity. The presence of similar diverticula has been, among others, stated in: Mus musculus (R a u the r, 1904, Szarski, 1935) Guinea Pig ( $R$ a u the r, 1904), Cricetus frumentarius (G rosz, 1905), Macroscelides and Tupaja $\mathrm{K}$ a u der $\mathrm{n}, 1911$ ). According to $\mathrm{Szarski}(1935)$ they have also been described by Gegenbaur in numerous Rodentia and Marsupialia. $\mathrm{R}$ a u the $\mathrm{r}$ (1904) has attempted to give an interpretation of those structures, and come to conclusion much different however from that of G od et $(l . c$.$) . He considers the presence of the prostatic diverticulum$ is a character rather primitive (a distinct separation of the cranially blind canalis urogenitalis from the urethra sensu stricto, which empties into this canal).

In the light of the mentioned above facts, it seems that the hypothesis of $\mathrm{G}$ odet, as being based on doubtful premises, is highly disputable.

Nevertheless, no definite conclusions as to the development of the male genital system in Insectivora can be stated before a suitable number of data is available.

Finally, some remarks concerning the terminology and classification of the accessory glands in Mammals.

The postulate of Mossman (1932) that in the anatomy of genital system in Mammals should be applied the terminology used in anatomy 
of man seems to be correct, although some exceptions from this rule are necessary. This, in particular, concerns the glands developed from the vas deferens, i. e. the vesiculae seminales and the gl. ampullarum. The term for the first glands has been assumed from the anatomy of man and is generally applied, although is not quite adequate (as a rule there are no spermatozoa within those glands). The second category of glands is in anatomy of man termed ampulla. This term, however, is much less adequate, since by this term we can mean an ordinary swelling of the ductus deferens (e.g. the proximal swelling in Sorex), as well as a true glandular structure containing in its wall excretory tubes (e.g. the distal swelling in Shrews). Besides, there are also in Mammals free ampullar tubes, which grow out beyond the wall of the vas deferens, to which this term does not refer at all. (See Discussion, p. 103). Therefore, the term glandulae ampullarum applied to the generality of those structure, and underlying their relation with the term ampulla, seems to be more correct (M o s s m a n, 1932).

Most authors emphasize that a uniform terminology applied to the ciescription of genital structures is a necessary condition in establishing their homology within a given grup of Mammals. Some authors, however, introduce new terms making difficult this kind of research.

G o d e t (1952) define the ampullary glands in Insectivora by the term "ampulae seminales", although in his main Mammals glandulae accessoriae classification he has assumed system term glandulae ampullarum. The same author but in a different paper ( $G$ ode t, 1951) give the second example of an inconsistency while describing the glands of the vas deferens in Mole: „S'il n'existe pas de vésicule séminale indépendante du canal défèrent chez cette espèce, on trouve à la base de l'épididyme, une formation sécrétoire, qui constitue cependant une véritable vésicule séminale". Thus, contradicting himself, he considers a structure being classified as gl. ampullarum $\mathrm{A}_{3}$ as a vesicula seminalis.

\section{REFERENCES}

1. A rnbäck-Christie-Linde A., 1907: Der Bau der Soriciden und ihre Beziehungen zu andern Säugetieren. Morph. Jb., 36: 463-514. Leipzig.

2. B e n g mark S., 1958: The prostatic urethra and prostatic glands. 1-128. CWK Gleerup. Lund.

3. B e n o it M. J., 1926: Recherches anatomiques, cytologiques et histophysiologiques sur les voies excrétrices du testicule chez les mammifères. Arch. Anat. Hist. Embr., 5: 175-412. Strassbourg.

4. Brambell F. W. R., 1935: Reproduction in the Common Shrew (Sorex araneus L.). II. Seasonal changes in the reproductive organs of the male. Phil. Trans., B. 225: $51-62$. London.

5. Brambell F. W. R. \& Hall K., 1936a: Reproduction of the Lesser Shrew (S. minutus L.). Proc. zool. Soc. London: 957-969. 
6. B r a mbe $11 \mathrm{~F}$. W. R. \& Hall K., 1936b: Anatomical and histological studies of an intersexual Lesser Shrew (S. minutus L.) with special reference to the affects of the male hormones on the uterus and vagina. J. Anat., 70: 339-348. London.

7. Dehnel A., 1\$52: Biologia rozmnażania ryjówki aksamitnej $S$. araneus L. w warunkach laboratoryjnych. Ann. Univ. M. Curie-Skłodowska., Sect. C, 6: 359-376. Lublin.

8. Delost P., 1951: I'utricule prostatique des foetus et des nouveaunés de sexe mâlě de Campagnol des champs (Microtus arvalis). Bull. Soc. Zool. France 76: $158-163$.

9. Delost P., 1955: Anatomie et structure histologique de l'appareil génital du Campagnol des champs (Microtus arvalis $\mathrm{P}$ allas) adulte en activité sexuelle. Bull. Soc. Zool. France, 80: 207-222.

10. Dis se 1 h orst R., 1904: Ausführapparat und Anhangsdrüsen der männlichen Geschlechtsorgane. Lehrb. vergl. mikr. Anat. Oppel, 4: 102-424. Jena.

11. Eadie W. R., 1947a: The accessory reproductive glands of Parascalops with notes on homologies. Anat. Rec., 97: 239-251. Philadelphia.

12. E a die W. R., 1947b: Homologies of the male accessury reproductive glands in Sorex and Blarina. Anat. Rec., 98: 347-360.

13. Eadie W. R., 1948: The male accessory reproductive glands of Condylura with notes on a unique prostatic secretion. Anat. Rec., 101: 59-80.

14. Eadie W. R., 1951: A comparative study of male accessory genital glands of Neurotrichus. J. Mammal., 32: 36-43. Baltimore.

15. F or s berg J. G., 1963: Derivation and differentiation of the vaginal epithelium. 1-197. Ifaran Ohlssons Boktryckerei. Lund.

10. Gerhardt U., 1938: Die accessorischen Geschlechtsärüsen. Bolk et al.. Handb. vergl. Anat. Wirbeltiere., 5: 855-894. Urban \& Schwarzenberg. Berlin und Wien.

17. G o d et R., 1949: Recherches d'Anatomie d'embryologie normale et éxpérimentale sur l'appareil génital de la Taupe (Talpa europea L.). Bull. Biol., 83: 25-111. Jaris.

18. Godet R., 1950: Evolution comparée des voies génitales mâles chez les Insectivores Lipotyphla. C. R. Acad. Sci.,231: 1094-1096. Paris.

19. Godei R., 1951: Morphogénèse comparée des voies génitales máles chez les Insectivores Lipotyphla. Ann. Sci. nat. (Zool.), 13: 277-289. Paris.

20. G o d e t R., 1952: Les glandes annexées a l'appareil génital chez les mammifères: homologies et classification. Mammalia., 16: 24-36. Paris.

21. Grassé P., 1955: Ordre des Insectivores. Anatomie et reproduction. Grassé, P.,: Traité de Zoologie, 17, 2: 1574-1641.

22. Grosz S., 1905: Beiträge zur Anatomie der accessorischen Geschlechtsdrüsen der Insectivoren und Nager. Arch. mikroskop. Anat., 66: 567-608. Berlin.

23. K a u de r $\mathrm{n}$ W., 1907: Beiträge zur Kenntnis der männlichen Geschlechtsorgane bei Insectivoren. Zool. Jb. Anat, 24: 521-552. Jena.

24. K a udern W., 1911: Studien über die männlichen Geschlechtsorgane von Insectivoren und Lemuriden. Zool. Jb. Anat., 31: 1-106.

25. Kratochvil J., 1960: Sexualdrüsen bei den Säugetieren mit Rücksicht auf Taxonomie. Symp. theriol. Brno: 175-187.

26. K wietniewski K., 1910: Zur Entwickelung der Wolffschen und Müllerschen Gänge bei Nagetier€n. Anat. Anz., 35: 240-256. Jena. 
27. Leydig F., 1850: Zur Anatomie der männlichen Geschlechtsorgane und Analdrüsen der Säugetiere. Z. wiss. Zool., 2. Leipzig.

28. Mombaerts J., 1944: Le sinus urogénital et les glandes sexuelles annexes du Hérisson (Erinaceus europaeus I.). Recherches anatomiques, histologiques, embryologiques et experimentales. Arch. Biol., 55: 393-554. Paris.

29. Mossman H. W., Lawlah W., Bradley J. A., 1932: The male reproductive tract of the Sciuridae. Amer. J. Anat., 51: 89-141. Philadelphia.

30. M ü 11 e r V., 1892: Uber die Entwicklungsgeschichte und feinere Anatomie der Bartholinischen und Cowperschen Drüsen des Menschen. Arch. mikroskop. Anat., 39. Berlin.

31. O u de m an s J. Th., 1892: Die accessorischen Geschlechtsdrïsen der Säugetiere. 91, Haarlem.

32. P e y r e M. A., 1959: Morphogènèse des voies génitales mâles de Galemys pyrenaicus G. (Mammifère, Insectivora). C. R. Acad. Sci., 294: 1569-1570. Paris.

33. Price M., 1953: The reproductive cycle of the Water Shrew, Neomys fodiens bicolor S h a w. Proc. zool. Soc., 123: 599-621. London.

34. Pucek Z., 1960: Sexual maturation and variability of the reproductive system in young Shrews (Sorex L.) in the first calendar year of life. Acta theriol., 3: 269-296. Bialowieża.

3.5. R a u the r M., 1904: Úber den Genitalapparat einiger Nager und Insektivoren, insbesondere die akzessorischen Genitaldrüsen derselben. Jena. Z. Naturw., 38: 377-472. Jena.

36. R a u ther M., 1909: Neue Beiträge zur Kenntniss der Urogenitalsystems der Säugetiere. Denkschr. mat.-naturw. Ges., 15, 3.

37. R a $\mathrm{t}$ h e r M., 1938: Uber den männlichen Genitalappart von Solenodon paradoxus B randt (Mammalia, Insectivora). Zool. Anz.,123: 65-78. Leipzig.

38. R a y n a d A., 1942: Recherches embryologiques et histologiques sur la différenciation sexuelle normale de la Souris. Bull. Biol. Supplément, 29: 1-114. Paris.

39. K a y n a u d A., 1951: Les glandes annexes du tractus urogénital des Compagnols agrestes (Microtus agrestis L.). Bull. Biol. 85: 323-372.

40. Rietschel P. E., 1929: Zur Morphologie und Histologie der Genitalausführungsgänge in Individual-cyclus der weissen Maus. Z. wiss. Zool., 135: 428-493. Leipzig.

41. Simps on G. G., 1945: The principles of classification and a classification of Mammals. Bull. Amer. Mus. Nat. Hist., 85. New York.

42. S t e l m a s i a k M., 1958: Mianownictwo anatomiczne. Warszawa, Państw. Zakł. Wyd. Lek. - Warszawa.

42. Stöhr Ph., Möllendorff W., Goerttler K., 1963: Lehrbuch der Histologie. Gustav Fischer. 1-606. Jena 1963.

44. Szarski K., 1935: Przyczynek do badań nad rozwojem i budową gruczolów dodatkowych (gll. accessoriae) dróg moczo-płciowych myszy białej. Archiwum Tow. Nauk. we Lwowie., 6: 1-142.

45. W e b e r M., 1898: Studien über Säugethiere. Jena. 1-132.

4f. W o $1 \mathrm{~s}$ k a J., 1952: Rozwój aparatu płciowego w cyklu życiowym Sorex arancus L. Ann. Univ. M. Curie-Skłodowska., Sect. C, 7: 497-539. Lublin.

Keceived March 20, 1965.

Department of Comparative Anatomy,

Wrocław University,

Wrocław, Sienkiewicza 21. 


\section{Alina KOWALSKA-DYRCZ}

\section{BADANIA POROWNAWCZE UKEADU PECIOWEGO MESSKIEGO NIEKTORYCH GATUNKÓW RYJŌWEK}

\section{Streszczenie}

Przeprowadzono analizę anatomiczno-histologiczną budowy: nasieniowodu i części miednicowej cewki moczowej oraz należących do nich gruczołów - u samców trzech gatunków ryjówek: Sorex araneus Linnaeus, 1758; Sorex minutus Linnaeus, 1766 i Neomys fodiens (P ennant, 1771). Ustalono rownież sposób i miejsce powstawania zawiązków gl. accessoriae w rozwoju embrionalnym. Analizą objęto samce dojrzałe płciowo, samce młodociane i zarodki wyżej wymienionych gatunków.

Opierając siẹ na trzech zasadniczych kryteriach: 1) rozwoju, 2) mikroskopowej strukturze, 3) umiejscowieniu tych struktur u osobników dorosłych - ustalono homologię tych narządów u badanych ryjówek. Stwierdzono, że: Budowa nasieniowodu jest identyczna $\mathrm{u}$ obu gatunków należących dlo rodzaju Sorex L. Proksymalne zgrubienie nasieniowodu spelnia tu funkcję zbiornika nasienia (funkcja gruczolowa jest nie większa, niż w innych partiach nasienicwodu). Zgrubienie dystalne, tworzy zaś właściwe gl. ampullarum. U Neomys występuje tylko zgrubienie dystalne (gl. ampullarum), odpowiadające temu u rodzaju Sorex. U wszystkich trzech gatunków występuje więc 1 para gl. ampullarum, najzupełniej sobie homologicznych. Brak vesiculae seminales.

Gl. prostaticae występują w postaci jednej pary gruczolów o podobnej budowie mikroskopowej. Są to złożone gruczoly pęcherzykowo-cewkowe, o zrazikowej strukturze. U $N$. fodiens budowa zlazikowa jest nieco słabiej wyrażona, niż u rodzaju Sorex, również w budowie nabłonka gruczolowego występują fewne różnice. Gruczoly te uchodzą 'u $S$. araneus i $N$. fodiens jedną parą przewođów wyprowadzających do cewki moczowej, u S. minutus najczęściej dwoma parami, a czasem większą ilością przewodów. W rozwoju zarodkowym gl. prostaticae powstają u $N$. fodiens i $S$. araneus $\mathrm{z}$ jednej pary zawiązków, wyrastających $\mathrm{z}$ bocznych ścian sinus urogenitalis, mniej więcej na poziomie ujść przewodów Wolffa, po jednym z każdej strony, - u S. minutus, oprócz głównej pary zawiązków bocznych, występują dodatkowo zawiązki brzuszno-boczne, w zmiennej ilości. Zmienna ilość przewodów grzbietowo-bocznych; prostata, występująca u tego ostatniego gatunku, w powiązaniu ze zmienną ilością zawiązków brzuszno-bocznych tych gruczolów sugeruje, że ilość zawiązków gruczcłowych wiąże się z ilością przewodów wyprowadzających (a nie płatów gruczołowych), występujących u doroslego samca. Wydaje się ponadto, że fakt występowania zmiennej ilości zawiązków prostata, a w związku z tym zmiennej ilości przewodów wyprowadzających gruczolu, nie jest zjawiskiem rzadkim również $\mathrm{u}$ innych ssaków. Budowa mikroskopowa $g l$. prostaticae, jak również sposób powstawania tych gruczołów (kosztem bocznych ścian sinus urogenitalis), wskazują, że u wszystkich trzech gatunków gruczoły te są homologiczne, a także homologiczne grupom: bocznym i brzusznej prostata u Rodentia.

U badanych gatunków ryjówek budowa pars prostatica uretlırae jest prosta, hrak jakichkolwiek ślepych wypuklin w okolicy colliculus seminalis, opisanych przez Godeta (1951) u rodzaju Crocidura (W a gler), jako kieszeń prostatyczna. $\mathrm{Na}$ granicy $p$. membranacea i $p$. spongiosa urethrae występuje natomiast dobrze 
wyksztalcona opuszka prącia (bulbus penis), w której leży zátoka cewki (sinus urethrae bulbi). Zatoka ta jest bardzo obszerna u obu gatunków rodzaju Sorex i dużo słabiej wykształcona u $N$. fodiens. U wszystkich trzech gatunków uchodzą do niej przewody gl. bulbo-urethrales. U Neomys cala p. pelvina urethrue wysłana jest nabłonkiem wielowarstwowym płaskim, rogowaciejącym, co - jak się wyjaje -- jest zjawiskiem wyjątkowym u ssaków. U wszystkich zbadanych ryjówek stwierdzono na terenie cewki moczowej brak gl. urethrales.

Gl. bulbo-urethrales występują zawsze w ilości 1 pary. Gruczoły te, ze względu na ich budowę mikroskopową (złożone gruczoły pęcherzykowo-cewkowe, o zwartej strukturze i zewnętrznej warstwie mięśni poprzecznie prążkowanych) wykształcenie i sposób ujścia przewodow wyprowadzających (jedna para długich przewodów, o charakterze gruczołowym, uchodzących do sinus urethrae bulbi), oraz sposób powstawania (z grzbietowo-bocznych ścian sinus urogenitalis, $w$ miejscu, gdzie przechodzi ona $z$ części miednicowej $w$ czçść jarnistą), należy uznać jako najzupełniej homologiczne u wszystkich trzech gatunków, jak równiė̇ homologiczne tym gruczołom $\mathrm{u}$ innych ssaków. $U N$. fodiens są une względnie mniejsze niż u rodzaju Sorex i mają bardzo silnie zredukowaną warstwę mięśni poprzecznie prążkowanych, co można uznać za cechę regresywną, wynikająça $z$ wodnego trybu życia tego zwierzęcia (u ssaków typowo wodnych gruczoly te $z$ reguly nie występują).

U dorosłych samców ryjówek nie stwierdzono żadnych śladów przewodów Müllera. Dystalny szczątek tych przewodów (utriculus prostaticus) występuje jedynie w okresie zarodkowym, jako krótki, ślepo zaczynający się kranialnie kanalik, leżący między przewodami Wolffa i lączący się z grzbietową ścianą sinus urogenitalis na poziomie ich ujść. Zanika on präwdopodobnie pod koniec życia embrionalnego.

\section{EXPLANATION OF PLATES}

Plate V.

Fig. 1. The urogenital system in $S$. araneus $\sigma^{*}$, ad. a - gl. am jullarum, b - bulbus penis, c - gl. bulbourethralis, $\mathrm{n}$ - proximal swelling of vas deferens, $\mathrm{p}$ - gl. prostatica, $\mathrm{u}-$ vesica urinaria. Magn. $1.7 \times$.

Fig. 2. Cross-section through the initial portion of vas deferens in S. araneus $\gamma^{\prime}$, ad. Magn. $200 \times$.

Fig. 3. The urogenital system in $N$. fodiens $\sigma$, ad. Explanations, see Fig. 1. Magn. $1.7 \times$.

Fig. 4. Longitudinal section through the proximal portion of vas deferens in $N$. fodiens, $\sigma^{x}$ ad. Magn. $50 \times$.

Fig. 5. Cross-section through the proximal portion of vas deferens in $N$. fodiens ad. Magn. $200 \times$.

Fig. 6. Cross-section trough the proximal swelling of vas deferens in $S$. minutus ơ, ad. Magn. $50 \times$.

Fig. 7. A fragment of the proximal swelling of vas deferens in $S$. araneus $\sigma^{x}$, ad. Magn. $200 \times$.

Fig. 8. A fragment of the proximal swelling of vas deferens in $S$. minutus $\sigma^{\prime}$, ad. Magn. 200 X. 


\section{Plate VI.}

Fig. 9. Cross-section through the proximal swelling of vas deferens in S. araneus $\sigma^{7}$. ad. (the beginning of breeding season). Magn. $17 \times$.

Fig. 10. Cross-section through the distal swelling of vas deferens (gl. ampullarum) in S. aroneus o", ad. Magn. $17 \times$.

Fig. 11. Cross-section trough the distal swelling of vas deferens (gl. ampullarum) in $N$. jodiens $\sigma^{*}$, ad Magn. $17 \times$.

Fig. 12. A fragment of distal swelling of vas deferens (gl. ampularum) in S. araneus $\checkmark$, ad. Magn. $200 \times$.

Fig. 13. A fragment of distal swelling of vas deferens (gl. ampullarum) in $N$. fodiens $\sigma$, ad. One sees eccrine secretion. Magr. $200 \times$

Fig. 14. Cross-section (slightly diagonal) through the distal swelling of vas deferens (gl. ampullarum) in S. araneus $\sigma^{*}$, juv. Magn. $200 \times$.

Fig. 15. A fragment of a cross-section through prostatic gland in $S$. araneus $\sigma^{x}$, ad. Magn. $60 \times$.

Fig. 16. A fragment of a cross-section through prostatic gland in $N$. fodiens $\sigma^{\prime}$, ad. Magn. $60 \times$.

Fig. 17. A fragment of prostatic gland in S. araneus $\sigma^{*}$, ad. Magn. $200 \times$.

Plate VII.

Fig. 18. A fragment of prostatic gland in $N$. fodiens $\sigma^{*}$, ad. One sees eccrine secretion. Magn. 200X.

Fig. 19. A fragment of prostatic gland in S. minutus $\sigma^{7}$, ad. Magn. $200 \times$.

Fig. 20. A fragment of a cross-section thrcugh prostatic gland in $N$. fodiens juv. $200 \times$.

Fig. 21. Cross-section (slightly diagonal) through $14.2 \mathrm{~mm}$ long embryo of S.araneus, immediately beyond the point at which the Wolffian ducts empty into the sinus urogenitalis. One sees the left bud of prostatic gland (marked by an arrow) growing from the lateral wall of the sinus. The right bud is missing due to slightly diagonal plane of the section, c - the lumen of the sinus urogenitalis, $\mathrm{r}$ - the intestine. Magn. $50 \times$.

Fig. 22. Cross-section through $15.2 \mathrm{~mm}$ long embryo of $N$. fodiens, immediately beyond the point at which the Wolffian ducts empty into the sinus urogenitalis. One sees the buds of prostatic gland, growing from the lateral walls of the sinus urogenitalis (one on each side at a time), marked by arrows. For explanations, see Fig. 21. Magn. 50 \%.

Fig. 23. Cross-section (slightly diagonal) through $13 \mathrm{~mm}$ long embryo of $S$. minutus, immediately beyond the point at which the Wolffian ducts empty into the sinus urogenitalis. One sees the left lateral bud of prostatic gland growing from the lateral wall of the sinus, and the left ventro-iateral (minute) bud. Both buds are marked by arrows. For the explanations, see Fig. 21. Magn. $60 \times$. 
Fig. 24. A fragment of a cross-section through the sinus urogcnitalis in $13.3 \mathrm{~mm}$ long embryo of $N$. fodiens. One sees a bud of gl. prostatica, growing from the lateral wall of the sinus (marked by an arrow). The distal, abortive portion (cut longitudinally) of the Mullerian duct adheres the dorsal wall of the sinus. The left Wolffian duct is on its right. c - sinus urogenitalis, $\mathrm{m}$ - ductus Miillcri, w - ductus Wolffi, Magn. 200x.

\section{Plate VIII.}

Fig. 25. A cross-section through the urethra in $S$. araneus $\sigma^{*}$, ad. in a level with crista urethralis. a - vas deferens, b - excretory duct of gl. prostatica, c - the lumen of the urethra, o - m. urethralis. Magn. 55X.

Fig. 26. A cross-section through the urethra in $S$. araneus $\sigma$, ad. in a level with colliculus seminalis. One sees the openings of vasa deferentia and of prostatic gland ducts. Explanations as in Fig. 25. Magn. 55×.

Fig. 27. A cross-section through the urethra in $N$. fodiens, $\sigma^{x}$, ad. in a level with crista urethralis. Explanations as in Fig. 25. Magn. 35X.

Fig. 28. A cross-section through the urethra in $S$. minutus $\sigma^{*}$, ad. in a level with crista urethralis, a - vas deferens, b - dorsal duct of the gl. prostatica, c - the lumen of the urethra, $\mathrm{d}-$ dorsn-lateral duct of the gl. prostatica o-m. urethralis. Magn. $55 \times$.

Fig. 29. A cross-section through the urethra in $N$. fodiens $\sigma$, ad. in a level with colliculus seminalis. One sees the openings of gl. prostatica ducts. Notations, see Fig. 25. Magn. $35 \times$.

Fig. 30. A cross-section through the urethra in $S$. minutus $\sigma$, ad. in a level with colliculus seminalis. One sees the opening of the right vas deferens and the openings of the dorsal ducts of $g l$. prostaticae. Notations, see Fig. 28. Magn. 55×.

\section{Plate IX.}

Fig. 31. A cross-section through the urethra in S. minutus $\sigma$, ad. in a level with ( $)$ ista urethralis. This specimen has more dorso-lateral aucts of gl. prostatıcae, than usual. Notations, see Fig. 28. Magn. 55 $\times$.

Fig. 32. A cross-section through the urethra in $S$. minutus $\sigma^{-1}$, ad. (the same specimen, as in Fig. 31), in a level with colliculus seminalis. One sees farther branches of dorso-lateral and lateral ducts of $g l$ prostaticae (3 right and 4 left ducts). On the right-hand side one sees the openings of three left dorso-lateral and lateral ducts of $g l$. prostaticae, that empty into the urethi'a. For explanations, see Fig. 28. Magn. $55 \times$.

Fig. 33. A fragment of a cross-section through the urethra in $N$. fodiens $\sigma$, ad. in a level with crista urethralis. One sees numerous tubes in the urethral epithelium. $\mathrm{c}-$ the lumen of the urethra. Magn. $200 \times$.

Fig. 34. A fragment of a cross-section through the urethra in $N$. fodiens $\sigma$, ad. in a level with crista urethralis. One sees the portions of a stratified, prismatic epithelium (marked by double arrow) and a stratified, flat epithelium (marked by an ordinary arrow) adjoining each other. Magn. $200 \times$. 
Fig. 35. A fragment of an urethral epithelium in $N$. fodiens $\checkmark$, ad. taken from the region of colliculus seminalis. One sees numerous leucocytes within the stratified, flat, keratinizing epithelium. Magn. $200 \times$.

Fig. 36. A fragment of a cross-section through the pars membranacea urethrae in $S$. araneus $\sigma^{*}$, ad. One sees epithelial tubules witinin connective tissue surrounding the canal of the urethra. Magn. $200 \times$.

Fig. 37. A fragment of the urethral epithelium in $N$. fodiens $\checkmark$, juv. taken from the region of colliculus seminalis. The epithelium is highly keratinized. Magn. $400 \times$.

Fig. 38. A cross-section through the pars membranacea urethrae in $S$ araneus $\sigma^{*}$, ad. c - the lumen of the urethra, $\mathrm{g}-m$. bulbo-cavernosus, $\mathrm{k}$ - the duct of $g$ !. bulbo-urethralis, o - m. urethralis, $\mathrm{t}$ - the gland associated with duct, $\mathrm{v}-$ the excretory ductulus of this gland. Magn. $55 \times$.

\section{Plate X.}

Fig. 39. A sagittal section through the bulbus peris in $S$. araneus $\sigma$, ad. The arrow indicates a cranial direction. $\mathrm{d}$ - corpus cavernosum penis, $\mathrm{g}-m$. bulbo-cavernosus, $\mathrm{h}$ - sinus urethrae bulbi, $\mathrm{n}$ - corpus spongiosum, $\mathrm{p}$ - pars membranacea urethrae, s - pars spongiosa urethrae. Magn. 17...

Fig. 40. A cross-section through the cranial portion of the bulbus penis in S. araneus $\sigma$, ad. The ducts of gl. bulbo-urethrales are denoted by an arrow. i $-m$. ischio-cavernosus. The remaining notations, like in Fig. 29. Magn. 17X.

Fig. 41. A sagittal section through the bulbus penis in S. minutus o", ad. The arrow indicates a cranial direction $\mathrm{k}$ - the duct of gl. bulbo-urethralis. The remaining notations, see Fig. 39. Magn. $17 \times$.

Fig. 42. A sagittal section through the bulbus penis in $N$. fodiens $\gamma$, ad. The arrow indicates a cranial direction. The remaining notations, see Fig. 41. Magn. 17X.

Fig. 43. A cross-section through the bulbus penis in $S$. arraneus $\sigma^{*}$, juv. The arrows indicate cross-sectioned ducts of gl. bulbo-urethrales. Fur explanation. see Fig. 41. Magn. 55X.

Fig. 44. A cross-section through the bulbus penis in $N$. fodiens $\sigma$, juv. The arrows indicate the ducts of gl. bulbo-urethrales. For explanation, see Fig. 41, Magn. 55 X.

\section{Plate XI.}

Fig. 45. A cross-section through the gl. bulbo-urethralis in S. araneus $\sigma^{\circ}$, ad. Magn. $17 \times$.

Fig. 46. A cross-section through the $y l$. bulbo-urethralis in $N$. fodiens $\sigma$, ad. Magn. 17x.

Fig. 47. A longitudinal section through the gl. bulbo-urethralis in $S$. araneus $\sigma^{*}$, juv. Magn. 200X.

Fig. 48. A fragment of a cross-section through the gl. bulbo-urethralis in S. arancus $c$, ad. Magn. 200 $\times$.

Fig. 49. A fragment of a cross-section through the gl. bulbo-urethralis in $N$. fodiens $\sim$, ad. One sees an exceedingly reduced sheath of striated muscle. Magn. $200 \times$. 
Fig. 50. A cross--section through the posterior part of the $14.5 \mathrm{~mm}$ long embryo of $S$. araneus. One sees pars phallica of sinus urogenitalis, (c) and the buds of gl. bulbo-urethrales (marked by an arrow) lying on both sides of the intestine ( $r$ ).

Magn. $55 \times$.

\section{Plate XII.}

Fig. 51. A cross-section through the posterior part of the $15.2 \mathrm{~mm}$ long embryo of $N$. fodiens. One sees the distal parts of the buds of gl. bulbo-urcthrales (marked by an arrow) lying within the blastemas on both sides of the intestine ( $r$ ). Magn. $55 \times$.

Fig. 52. A fragment of a sagittal section through the posterior part of the $11 \mathrm{~mm}$ long embryo of $S$. arancus. One sees the course of the sinus urogenitalis and the bud of the sinus urethrae bulbi, c - the lumen of the sinus urogenitalis, $\mathrm{h}$ - the bud of the sinus urethrae bulbi, $\mathrm{r}$ - the intestine, $\mathrm{u}$ - the vesica urinaria. Magn. $60 \times$.

Fig. 53. A cross-section through the $8.5 \mathrm{~mm}$ long embryo of $S$. araneus in a level with the openings of the Wolffian ducts into the sinus urogenitalis. One sees a pair of Müllerian ducts, lying between both Wolffian ducts, c - the lumen of the sinus urogenitalis, $\mathrm{m}$ - ductus Mülleri, w - ductus Wolffi. Magn. $200 \times$.

Fig. 54. A cross-section through the sinus urogenitalis of the $14.2 \mathrm{~mm}$ long embryo of $S$. araneus in a ievel with the openings of Wolffian ducts. For explanations, see

Fig. 53. Magn. 200X.

Fig. 55. A cross-section through the sinus urogenitalis of the $13 \mathrm{~mm}$ long embryo of $S$. minutus, in a level with openings of the Wolffiail ducts. For explanations, sec

Fig. 53. Magn. $200 \times$. 
PANSTWOWE WYDAWNICTWO NAUKOWE * WARSZAWA 1960 Naklad 1080 egz. Obj. ark. wyd. 9,0. Maszynopis otrzym. 26.I.1966. Podpisano do druku 27.X.1966, druk ukończ. w październiku $1966 \mathrm{r}$. Pap. druk. sat. kl. 111 80 g. Format $B 1$.

Bialostockie Zakłady Graficzne. Zam. $396 *$ D-3. Cena $40 \mathrm{zl}$. 

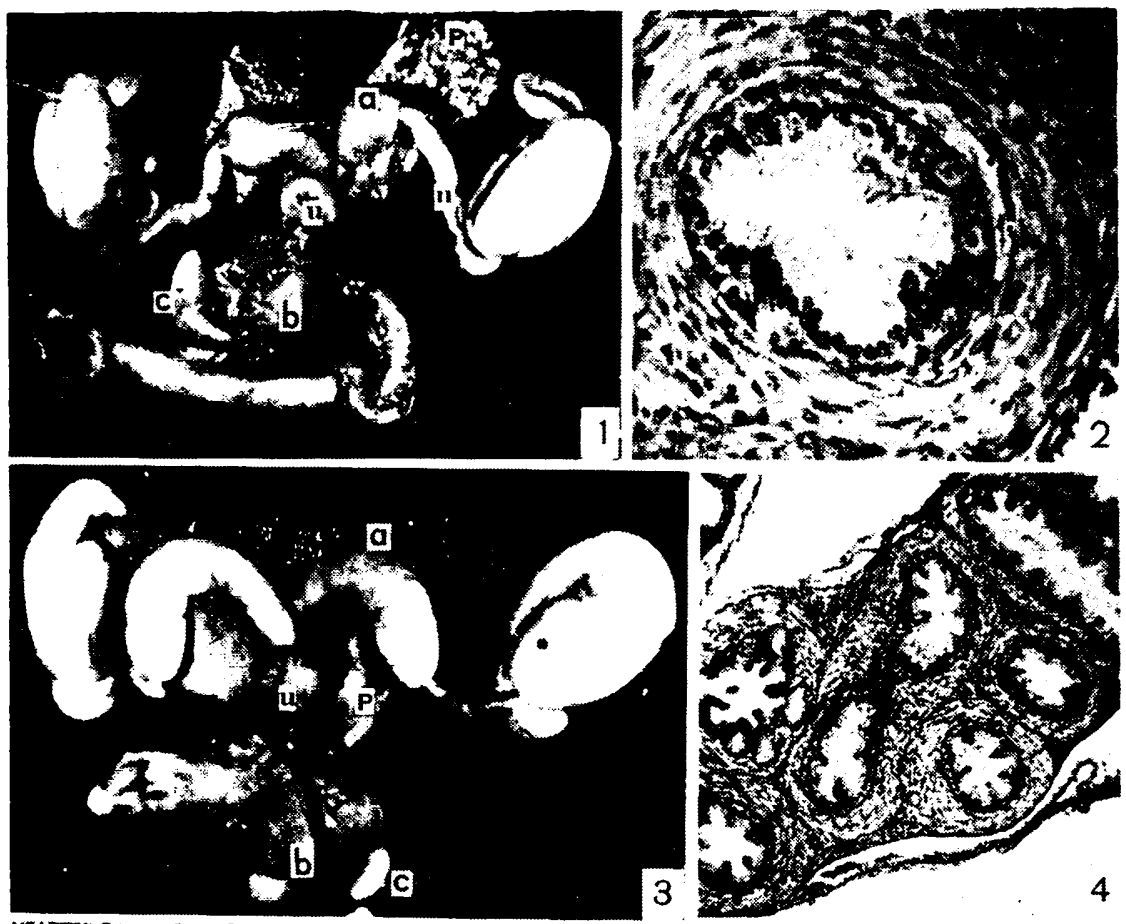
17f

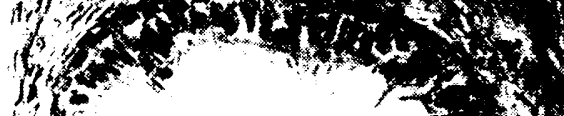
(1)

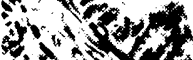

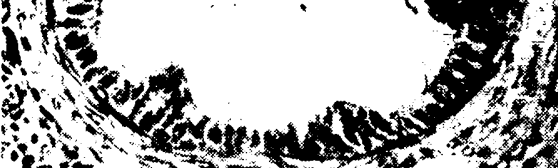

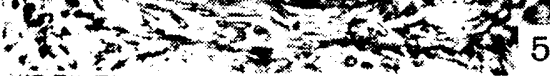

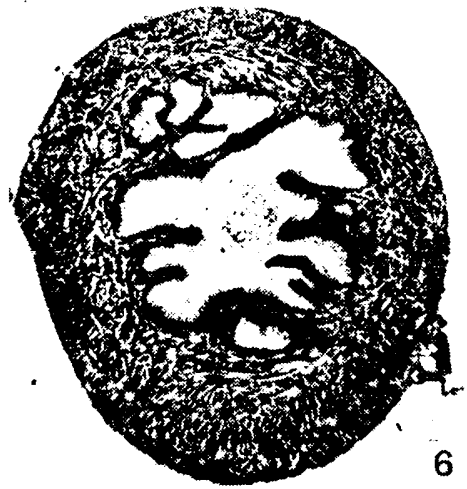

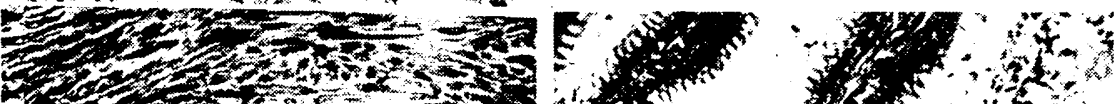

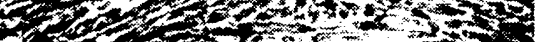

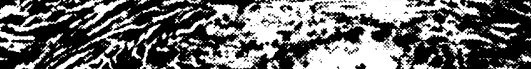

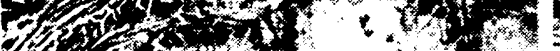

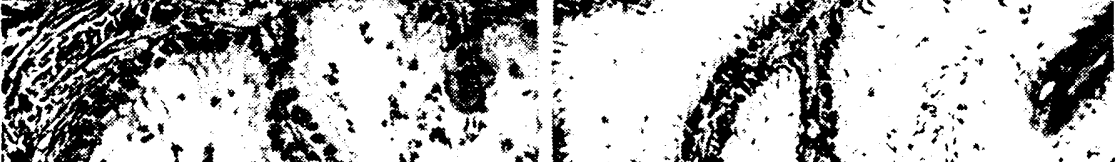

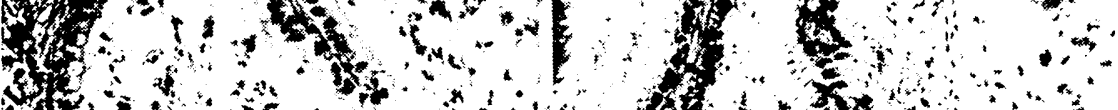
ato 

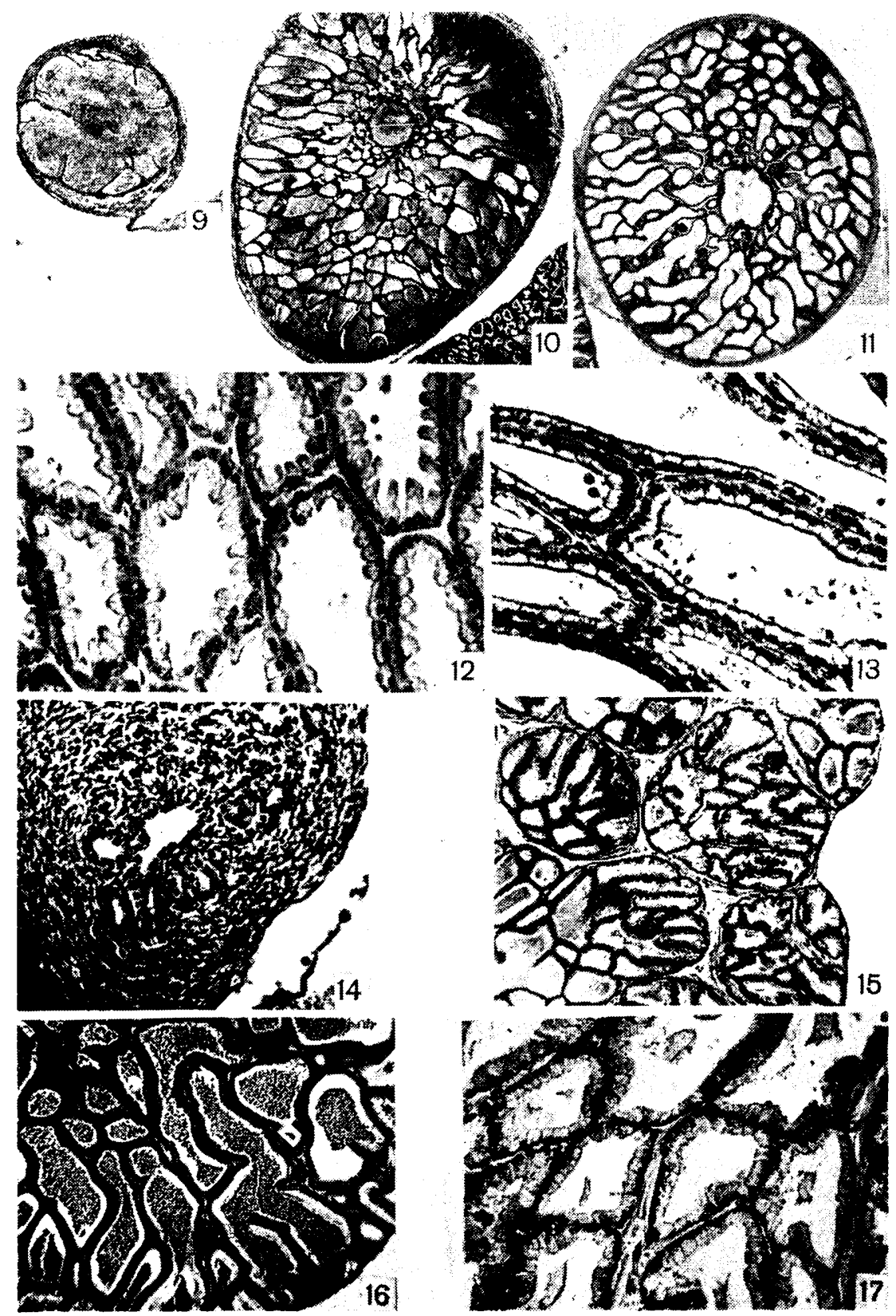

12

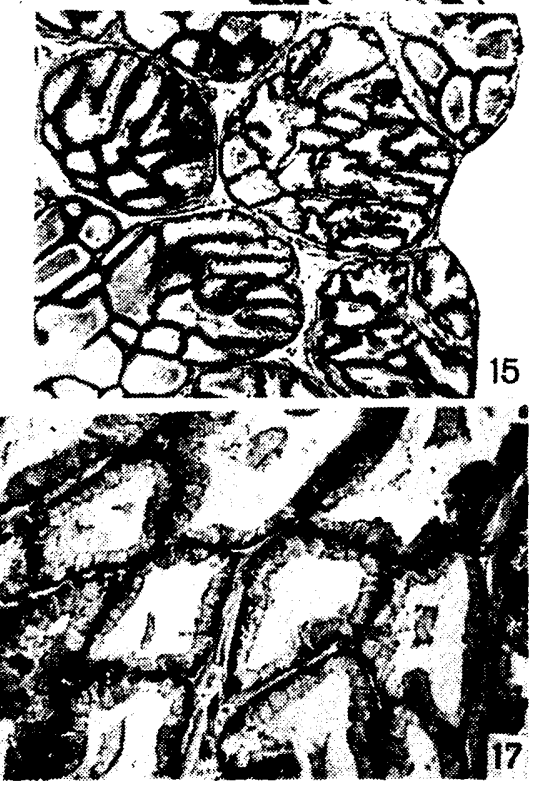




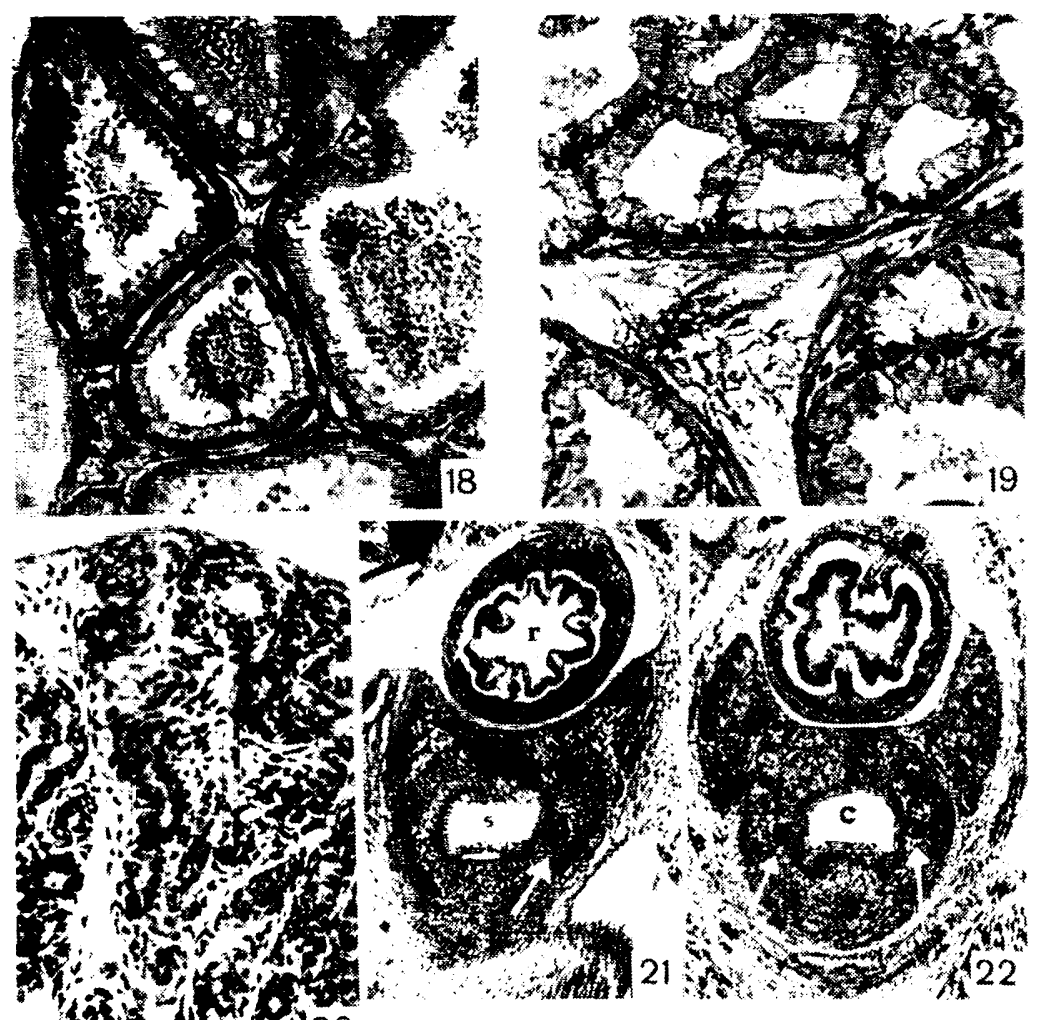

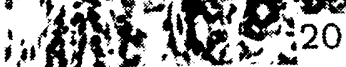
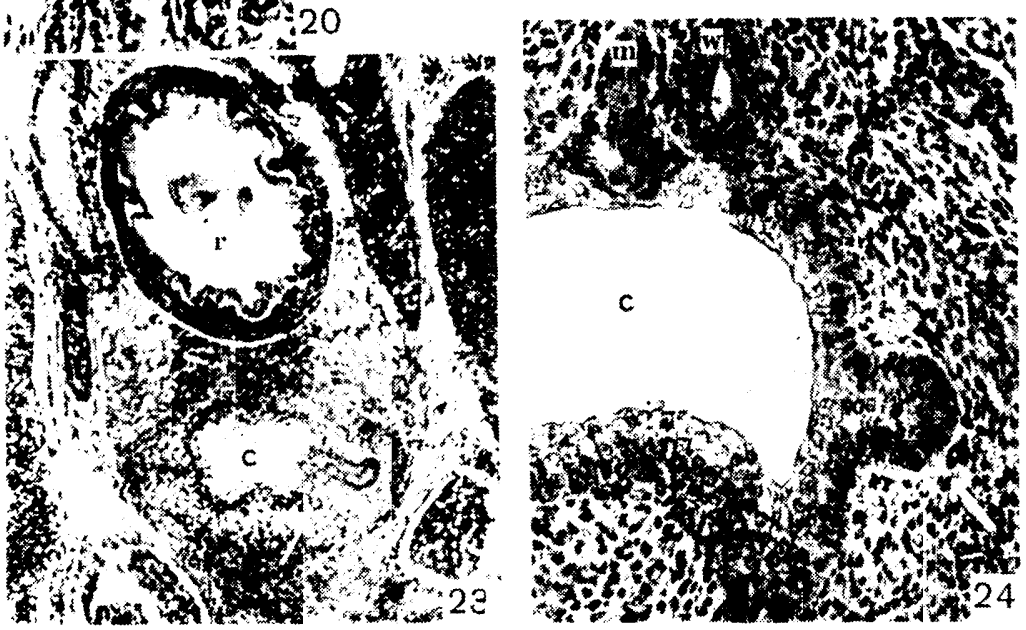

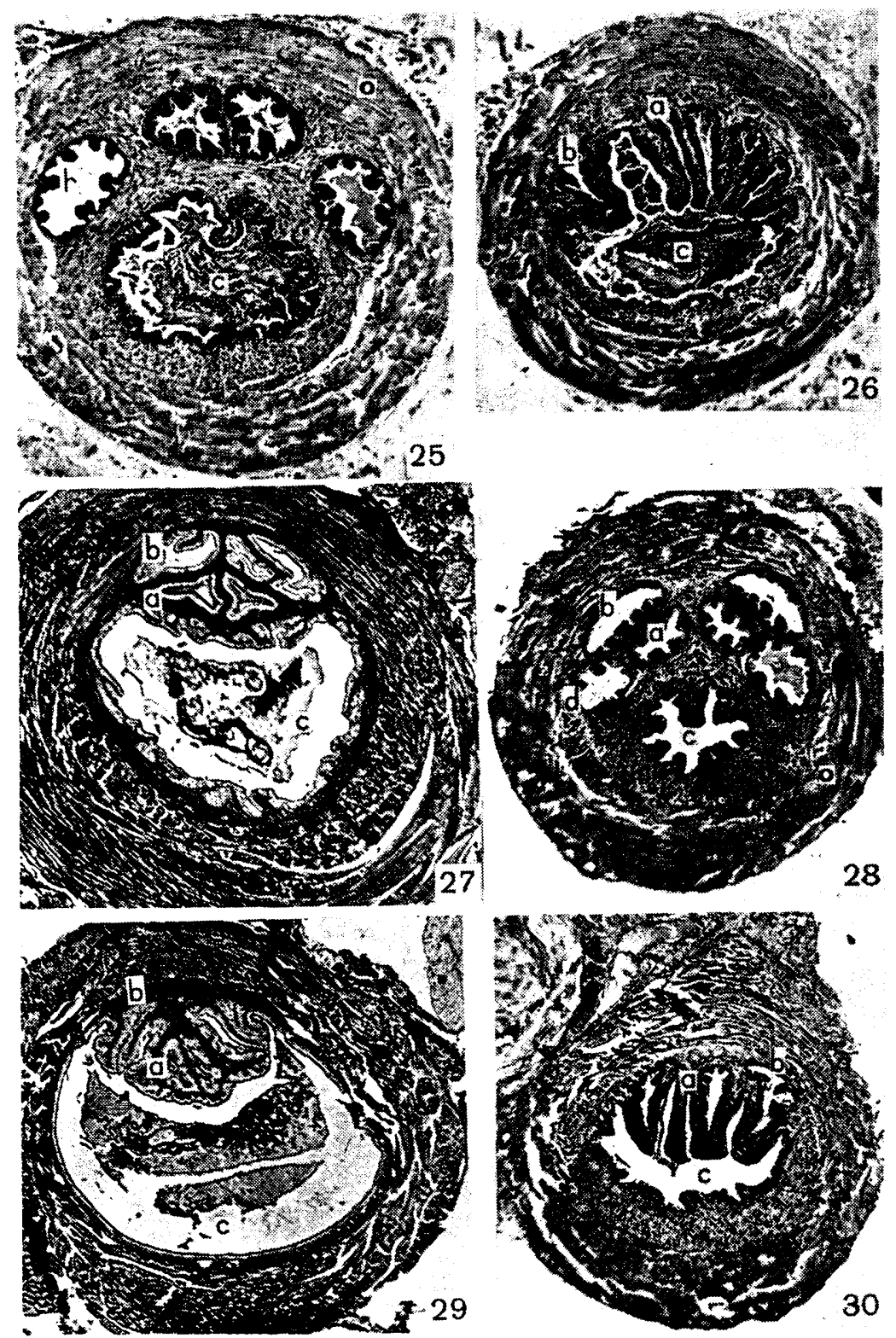


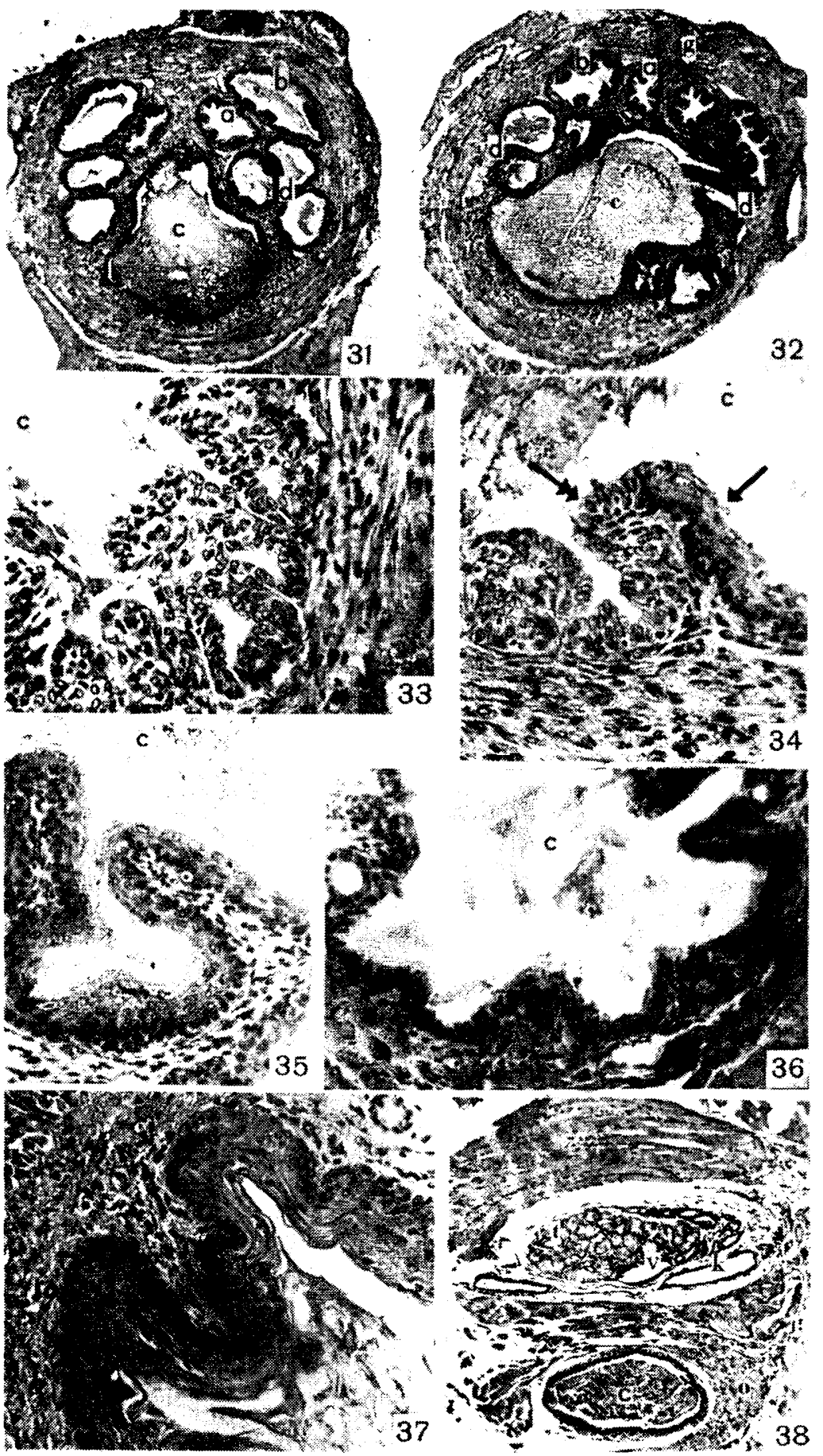



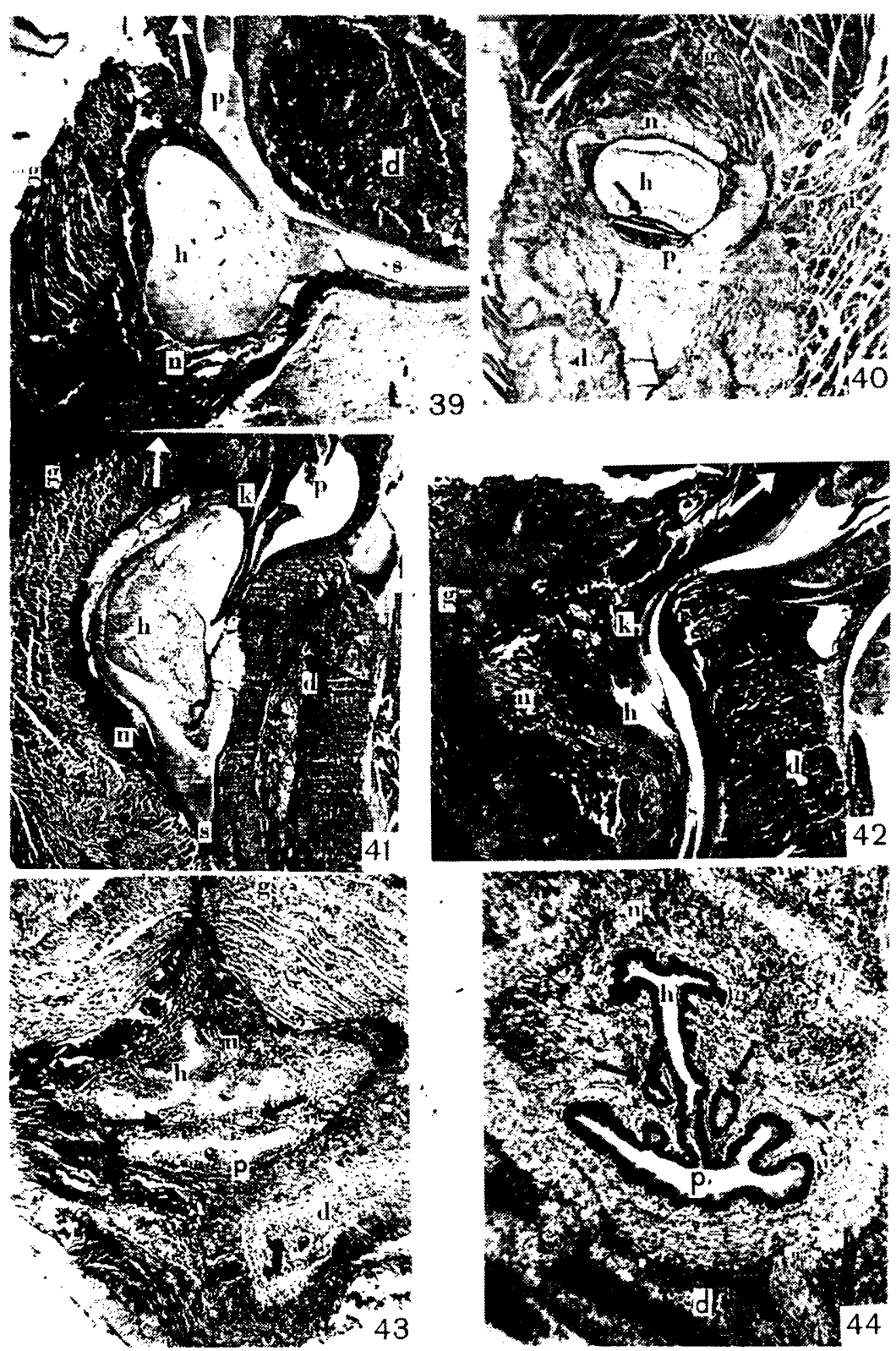

W.4.

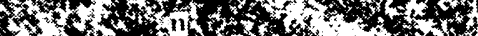

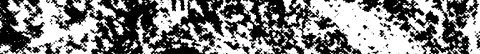

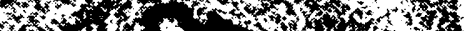

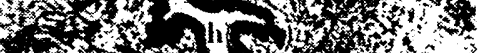

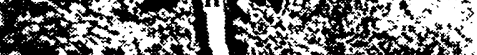
tond

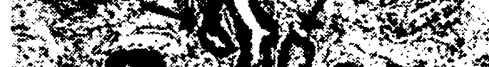

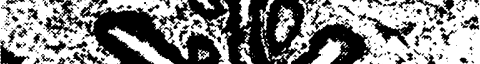

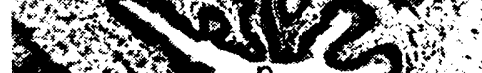

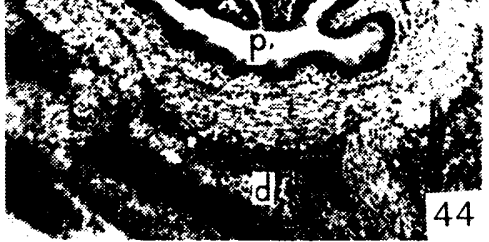



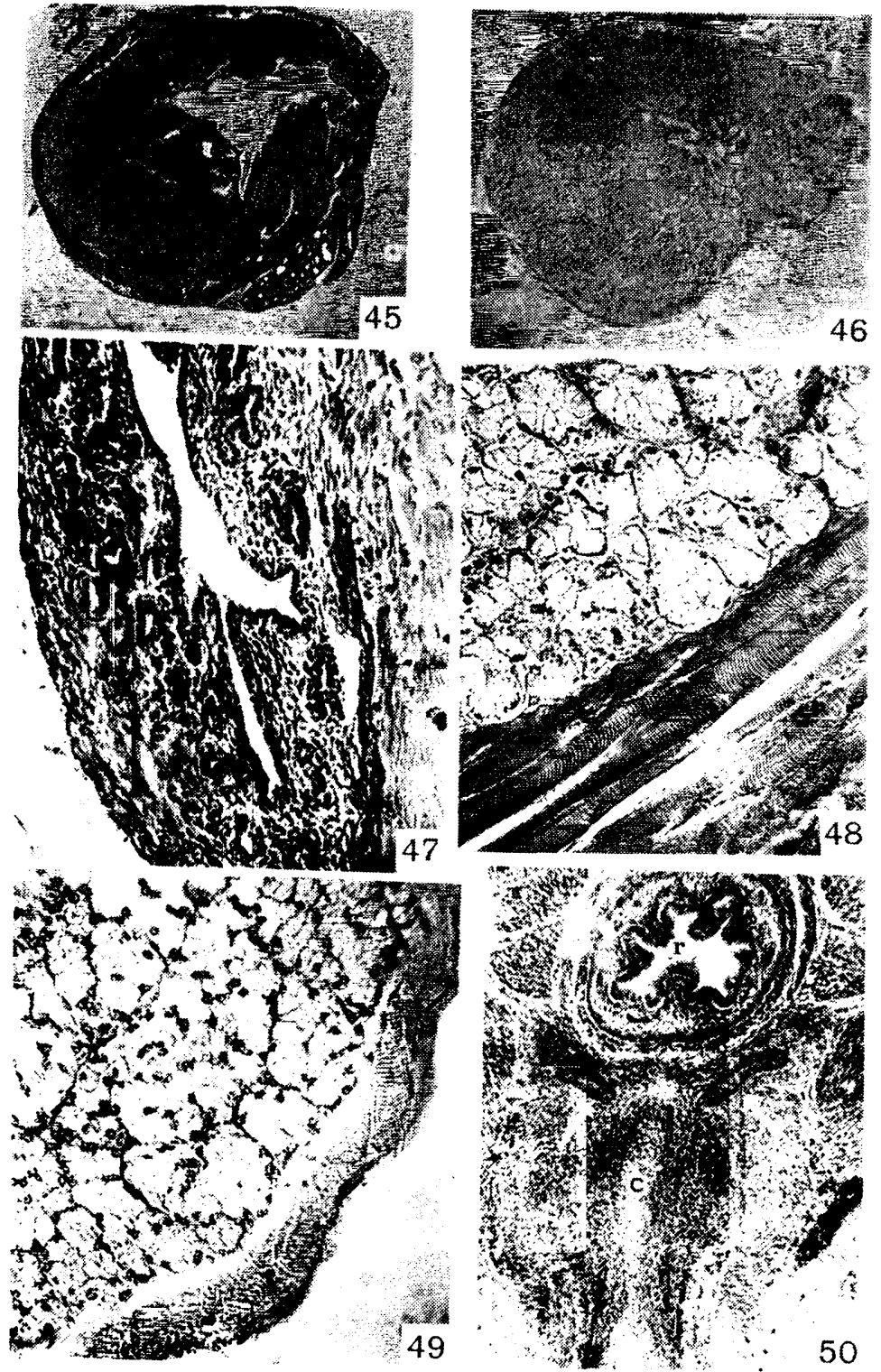


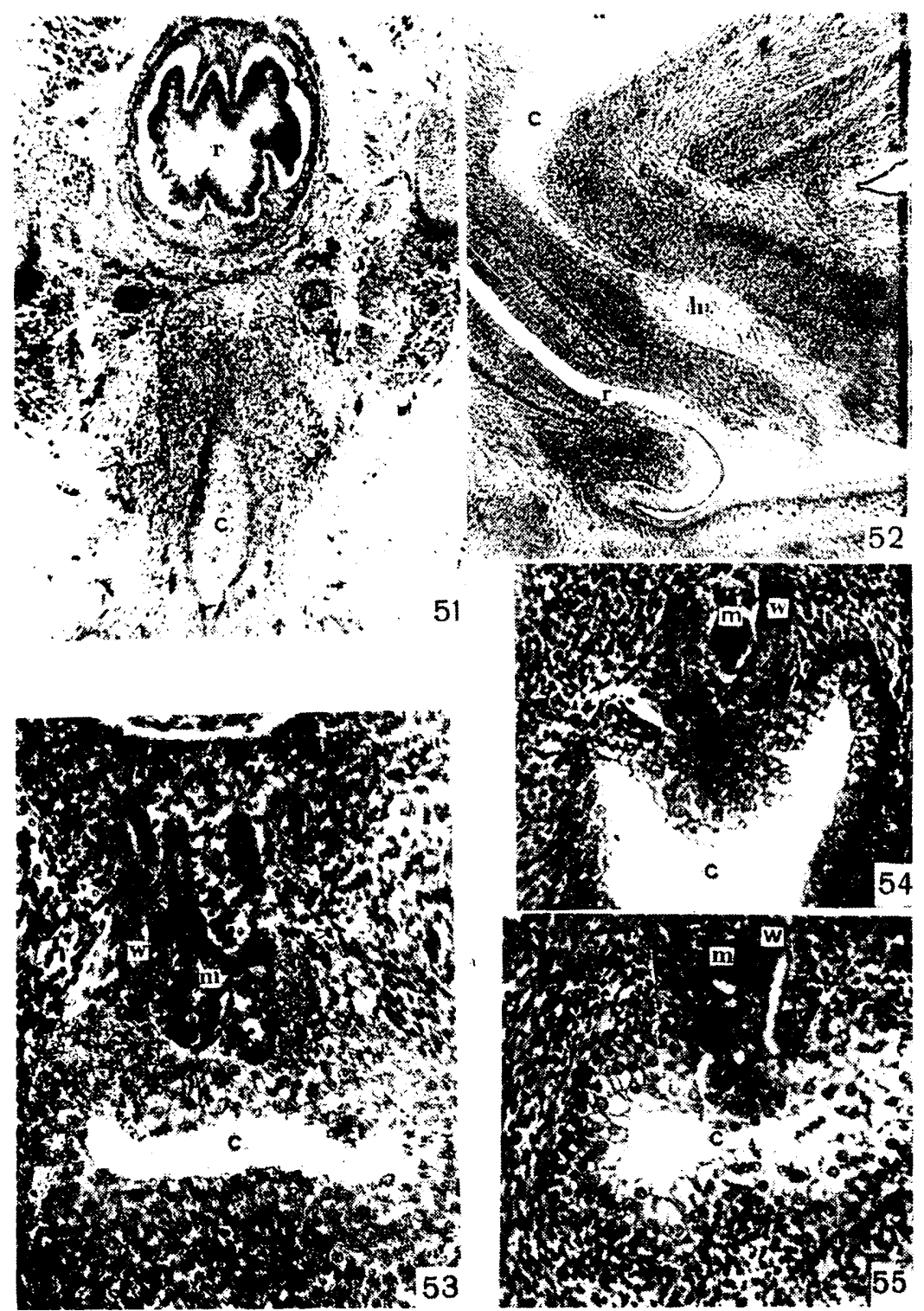

